Article

\title{
INFLUENCE OF SOCIODEMOGRAPHIC, ECONOMIC AND EMPLOYMENT-RELATED FACTORS ON SICK LEAVE DUE TO MENTAL ILLNESS. A RETROSPECTIVE STUDY IN AN INDUSTRIALIZED REGION IN SOUTHERN EUROPE.
}

Fernando Fuertes-Guiro ${ }^{1, *}$, Carmen Marqués-Gaspar ${ }^{2,}$ Ajda Amet ${ }^{2}$ and Luis FernándezBengoa $^{3}$

1 Faculty of Medicine and Health Sciencies, Universitat Internacional de Catalunya

2 Egarsat, Mutual Society for Work Accidents and Work-Related Illnesses, Spain

3 Faculty of Psychology, Universitat de Barcelona, Spain

* Correspondence: ffuertes@uic.es; Tel.: +34609303857

\begin{abstract}
Background: This study identifies and analyzes those variables that may influence sick leave due to mental illness, based on a retrospective descriptive study of a mutual insurance company in the industrialized region of southern Europe (Catalonia). (2) Methods: All workers who were on sick leave due to mental illness during the period 2009-2019 were included in the study. The relationships between sick leave due to mental illness and social/employmentrelated and economical and demographic factors were analyzed using multivariate logistic regression and Cox regression model. (3) Results: The period studied included 34,764 workers. Anxious-depressive disorders account for $83.3 \%$ of the diagnosed mental disorders. The age cohorts between 30 and 50 years represent $60 \%$ of the affected workers. Highest income and high population density regions are the most affected. The levels of mental illness are higher in spring and summer. Professions related to manufacturing industry, automobile mechanics companies, the hospitality industry, education and healthcare and social service companies was more heavily affected. (4) Conclusions: Population density and GDP per capita, the age cohort, the season of the year, the type of payment, the type of contract, and the worker's business and profession can predict the appearance of sick leave due to mental illness. Mutual insurance companies should plan interventions to minimize these factors and avoid the socioeconomic consequences.
\end{abstract}

Keywords: Sick leave, mental illness, predictors, prevention

\section{Introduction}


Temporary disability is a situation in the working life of workers which is very difficult to evaluate, with a high incidence and repercussions on a country's social, economic, political and business environment.

Mental illnesses are considered one of the causes of long-lasting and recurrent SL, and permanent disability in its various forms (1-3). These data are a reflection of the pandemic nature of these illnesses in the contemporary world: anxiety disorders, dissociative and somatoform disorders, and depressive disorders are the second ranked cause of SL due to common illnesses in Spain and the third ranked in Europe $(4,5)$. According to various studies, their prevalence is calculated at between 15 and $25 \%$ of causes of primary healthcare appointments, where SL certificates are issued (6).

The economic implications of SL due to mental illness are so important that it is the second highest cost to the public purse (7). In addition, once the patients return to work, their new situation affects their performance. Meanwhile, some companies cannot accept these workers until their treatment has finished and there are no indications that their situation will have a negative impact on their working environment (e.g. commercial airlines, companies undertaking hazardous work).

Socioeconomic, cultural and demographic risk factors for the development of mental illness have been extensively studied in the scientific literature (8-13). The published studies related to this health problem have increased considerably in the last 15 years, due to the increase in mental illness. Scientific evidence on risk factors associated with SL due to mental illness has also been published in the literature. As a result, a systematic review in 2011 (14) identified the following more or less consistent risk factors or predictors for SL due to mental illness: age (older than 50 years is associated with continuing disability and longer time taken to return to work), history of previous SL (patients with previous SL due to mental illness are more likely to take further SL), negative recovery expectation (predicting a longer time taken to return to work), socio-economic status (lower socio-economic status is a high risk factor for long-term disability), unemployment (which predicts long-term disability), and quality and continuity of occupational care (workplace interventions reduce long-term disability). Other studies have associated SL due to mental illness with other factors: level of education (predicting a longer time taken to return to work) (15), gender (women have higher rates of SL due to affective disorders than men) (16), poor employment conditions (harassment and bullying are associated with high rates of SL) (17), sociodemographic factors (living alone and residing outside big cities increase SL) (18), the employer's economic activity (working in the real estate and construction sector are associated with an increased probability of long-term SL) $(19,20)$ and the type of social security contributions and type of contract (long-term SL is significantly associated with having a fixed-term contract) (20). Meanwhile, some socioeconomic outcomes have been addressed in the literature (21-23), which has highlighted the influence of inequalities and economic differences among workers on SL due to mental illness. This scientific evidence often addresses mental illnesses as a whole rather than each specific mental pathology, although illnesses related to affective symptoms known as common mental disorders (anxiety and depression) and alcohol abuse and dependence have been the most widely studied (24).

Mutual insurance companies working with the National Institute for Social Security (NISS) are non-profit institutions overseen by the Spanish Ministry of Employment and Social Security. The employer chooses the mutual insurance healthcare provider, and their income comes from the fees that both companies and self-employed workers pay to the General Social Security Treasury. Their activities are subject to the applicable legislation at all times, and limited to companies and self-employed workers with a workplace on Spanish territory. The mutual insurance companies are simultaneously owners and clients. SL situations are managed by the NISS, normally working 
with the network of mutual insurance healthcare providers for occupational accidents and illnesses. These mutual insurance companies provide occupational healthcare, and are also responsible for the ongoing medical follow-up of patients on SL not related to an occupational accident or disease, in order to prevent absence from work due to unnecessary or prolonged illness.

In sick leave, rentier absenteeism is considered situations where there are no objective medical reasons for absence from work in which the individual concerned aims to receive a salary without working for a period of time. This is a problem that has not been eradicated and entails a major expense in State budgets and affects the balance of those budgets. Mutual insurance companies have to identify the causes, especially in pathologies with the highest incidence, such as mental illnesses.

Even taking into account the high incidence and prevalence of mental illness and its impact on temporary disability in employment as well as the progress made in its prediction, more studies to identify new predictors are still needed (and also those related to different regions in the world) (24), and to reinforce the scientific evidence from those already identified. Workers with these pathologies (some more than others) are known to have a higher risk of absenteeism, rentier absenteeism, and of poorer performance at work after returning. This study is presented with this in mind.

Considering that mental illnesses have risk factors in the demographic, socioeconomic and occupational spheres, we hypothesized that based on the data that have been obtained on retrospective information for 34,764 patients taking SL due to mental disorders according to the International Statistical Classification of Diseases and Related Health Problems (ICD-9th revision, Spanish version) from a database of a mutual insurance NISS healthcare providers over a period of 10 years in an industrialized region in Southern Europe (Catalonia), we would be able to identify and evaluate predictors that may influence SL due to mental illness, in order to be able to take action and thereby reduce their socioeconomic consequences and provide mutual insurance companies with preventive measures for their insured workers. First, the three groups of variables were identified, selected and processed as follows: sociodemographic (gender, age, age cohort, GDP per inhabitant and population density); employment-related (month of start of $\mathrm{SL}$, month of return to work, year of SL, cause of return to work, duration of SL) and economic (type of payment, type of social security contribution, activity of the company and occupation of the worker). Subsequently, a descriptive study of the variables selected for each mental pathology for each ICD-9 group in the insured employed population selected for the period analyzed was carried out. Finally, the influence of each variable on the prediction of sick leave was evaluated for each group of mental disorder in the working population studied.

\section{Materials and Methods}

\section{Selection of the study population}

This study was carried out at the Mutua Egarsat, a mutual insurance company working with the Spanish National Social Security Institute. In 2018, Egarsat had 35,034 member companies to cover occupational injuries and illnesses, and 23,910 companies for non-work-related injuries or illnesses. In total, the mutual insurance company covers 291,103 workers $(281,847$ employees and 9,256 self- employed workers) for occupational injuries or illnesses and 266,051 workers (204,643 employees and 61,408 self- employed workers) for non-work-related injuries or illnesses.

All the diagnoses of patients included in the computerized records of the mutual insurance company Egarsat who were on SL due to mental illness between January 2009 and June 2019 were 
included in the study, based on the diagnoses coded according to ICD-9. It is estimated that the sample size will enable detection of differences with a probability greater than $90 \%$ with a bilateral significance of $5 \%$ (HR 1.21).

The following were excluded from the study: a) diagnoses and patients with erroneous or inconsistent or repeated data, b) workers living outside Catalonia, c) those under 16 years old, d) those beginning SL outside the study period but with a duration included in the study period, e) SL beginning in the study period, but continuing after the study period. Only the events that started and ended in the study period were therefore included in the study. Other selection criteria were: a) workers with more than one period of SL with the same diagnosis during the study period were considered as new events if the period between leaves of absence was more than 180 days; otherwise, a single period of SL was considered, and b) workers with more than one period of SL with different diagnoses during the study period were considered as different events, regardless of the time elapsed between episodes or illnesses), c) Selection of the main diagnoses in each illness.

\section{Ethical-legal considerations}

As this is a retrospective descriptive study of computerized patient data, it was not necessary to obtain informed consent from the workers who are the subject of this study. All the data obtained was treated with the confidentiality stipulated in the current legislation. All procedures designed and used in this study comply with the ethical standards of Spanish and International organizations and committees and with the 1975 Declaration of Helsinki and its 2008 revision.

\section{Data Collection}

All the diagnoses of mental illness were obtained from the general Egarsat database. Once obtained, they were adapted to the working population and the number of records for each pathology to be studied by the Spanish version of the ICD-9, providing the diagnostic groups:

-Schizophrenic disorders (ICD-9 diagnostic group 295): mental disorders characterized by distortions of perception, thought and emotions as well as inappropriate affective manifestations.

-Episodic mood disorders (ICD-9 diagnostic group 296): alterations in mood or affectivity in prolonged periods of depression or euphoria (mania).

-Delusional disorders and other nonorganic psychoses (ICD-9 diagnostic groups 297 and 298): mental illnesses characterized by an acute onset of psychotic symptoms such as delusions, hallucinations and perceptual disorders, with significant behavioral disturbance.

-Anxiety, dissociative and somatoform disorders (ICD-9 diagnostic group 300): various forms of mental illnesses characterized by anxiety, fear and associated behavioral changes, which involve mental apprehension, physical tension, physical symptoms, and dissociative and somatoform anxiety.

-Personality disorders and disturbance of conduct not elsewhere classified (ICD-9 diagnostic groups 301 and 312): alterations that tend to be persistent and are the expression of a lifestyle and of the individual's characteristic way of relating to himself and to others.

-Alcohol dependence syndrome (ICD-9 diagnostic group 303): a set of physical, behavioral and cognitive manifestations in which alcohol consumption acquires the highest priority for the individual. 
-Drug dependence and nondependent abuse of drugs (ICD-9 diagnostic groups 304 and 305): a set of physical, behavioral and cognitive manifestations in which the consumption of a drug (except alcohol), acquires the highest priority for the individual.

-Special symptoms or syndromes not classified and physiological malfunction arising from mental factors (ICD-9 diagnostic groups 306 and 307): psychological conditions not included in other categories and dysfunctions produced by mental factors without objectifying organicity.

-Acute reaction to stress (ICD-9 diagnostic group 308): mental disorders that appear as a direct consequence of a severe acute stress or a sustained traumatic situation.

-Depressive disorder not elsewhere classified (ICD-9 diagnostic group 311): disorders that do not fulfil the characteristics of the depressive episodes noted in other categories but with an overall diagnostic impression that indicates that they are depressive in nature.

The independent variables (predictors) of mental events or illnesses (dependent variables) considered in this study were classified into 3 groups as follows:

1. Sociodemographic independent predictors:

- Population and region: the workers were grouped by Catalan region according to gross domestic product (GDP) per inhabitant and population density, based on the municipality where their declared domicile was located in the Catalan territorial organization of 2015 (containing 42 regions).

- Age: the worker's exact age when the period of SL began.

- Age cohort: in order to carry out the statistical study with more approximate demographic data, six cohorts were designed for this study: $\leq 20$ years, 20 - 29 years, 30 - 39 years, 40 - 49 years, 50 59 years, $\geq 60$ years.

- Gender: Dichotomous male/female variable.

2. Employment-related independent predictors.

- Month of start of SL: numbered from 1 to 12 (January to December).

- Month of return to work: numbered from 1 to 12 (January to December).

- Year of the beginning of SL: year in the database that the family doctor gave the SL to worker.

- Duration of the SL, in days.

- Cause of the return to work after SL, according to the internal code of the Egarsat mutual insurance company. There are five possible causes: Healing, Death, Medical inspection, Improvement permitting work, Administrative.

3. Economic predictors:

- Type of payment during the SL period: the method by which the receives payment. There are three possible methods: 1 . Delegated payment (the company pays the worker the financial benefits during the SL period); 2 . Direct payment (the mutual insurance company pays the worker, for self-employed workers or those ineligible for the delegated payment from the 
beginning of the SL period); 3 . Loss or termination of the delegated payment, while the worker is still on leave from work, leading to direct payment (the mutual insurance company is responsible for the financial benefit).

- Type of contract: type of employment contract that the worker has according to Spanish law. There are three possible types: general system, self-employed and others.

- Profession of the worker, as defined by the National Occupation Code (NOC, 1994) (24). These were classified into 10 groups: business management and public administrations; scientific and intellectual specialists and professionals; support specialists and professionals; administrative employees; restaurant, personal, protection and sales service workers in stores; skilled agriculture and fisheries workers; artisans and skilled workers in manufacturing; construction and mining industries; plant and machinery operators and assemblers; unskilled workers.

- Company's business activity, according to the classification of the National Code of Business Activities (NCBA, 2009) (25). These were classified in 22 groups: agriculture, forestry and fishing; construction of roads and railways; domestic workers; extra-territorial bodies and organizations; financial leasing; gambling and betting activities; legal and accounting activities; health and social service activities; manufacturing; mining and quarrying; other accommodation (host); postsecondary non-tertiary education; production of electricity; public order and safety activities; public relations and communication activities; renting and leasing of agricultural machinery ; repair of communication equipment; residential nursing care activities; software publishing; taxi operation; waste collection treatment and disposal activities; wholesale trade of motor vehicle parts and accessories.

\section{Statistical analysis}

Descriptive statistics were obtained for each of the selected variables. The categorical variables (dichotomous and ordinal) are expressed as numbers with corresponding percentages. The continuous variables are expressed as means with standard deviations, or in the case of nonparametric data, as medians with interquartile ranges (IQR). Continuous numeric variables will be transformed into categorical ordinals where possible.

Multivariate logistic regression was used to estimate the effect of each predictor variable on each mental pathology group (dichotomized versus others) when the response variable was categorical. The strengths of the associations were estimated using the odds ratios and confidence intervals (CI) of $95 \%$. The results were corrected for multiple comparisons setting the p-value of the cut-off to either 0.05 or 0.01 (high significance). Cox regression model will be used for the duration of the SL.

The Chi-squared test (or Fisher's exact test, if applicable) indicator was used to assess the goodness of fit and predictive power of each regression.

All the statistical analysis were carried out using version 23 of the SPSS software (SPSS Inc., Chicago, USA).

\section{Results}

Once the years of study were delimited in the computer system, 42,348 records were obtained, which after filtering with the inclusion and exclusion criteria were reduced to 34,764 workers, of whom 13,770 (39.6\%) were men and 20,994 (60.4\%) were women ( $<<0.05)$. (Fig 1). 


\section{Descriptive results}

The descriptive results of the dependent variables are presented in Table 1 and Table 2. When grouped by diagnosis anxiety, dissociative and somatoform disorders account for $76 \%$ of the illnesses studied (26,419 cases), episodic mood disorders account for $8.3 \%$ (2,888 cases) and depressive disorders $7.3 \%$ (2,536 cases).

The age cohorts between 30-50 years old account for $60 \%$ of the illnesses. The Catalan regions most affected by mental illness were those with the highest income levels (GDP of more than $€$ 30,000 per capita), accounting for $83.84 \%$ of the illnesses registered, and the regions with a population density greater than 1,000 inhabitants $/ \mathrm{km} 2$ account for $77.59 \%$ of the cases of psychiatric illness observed. The months of the year with the most patients starting SL due to mental illness were February, May and June, and the months with the fewest patients starting SL were August and December.

Fig 1. Flow chart of the study participants

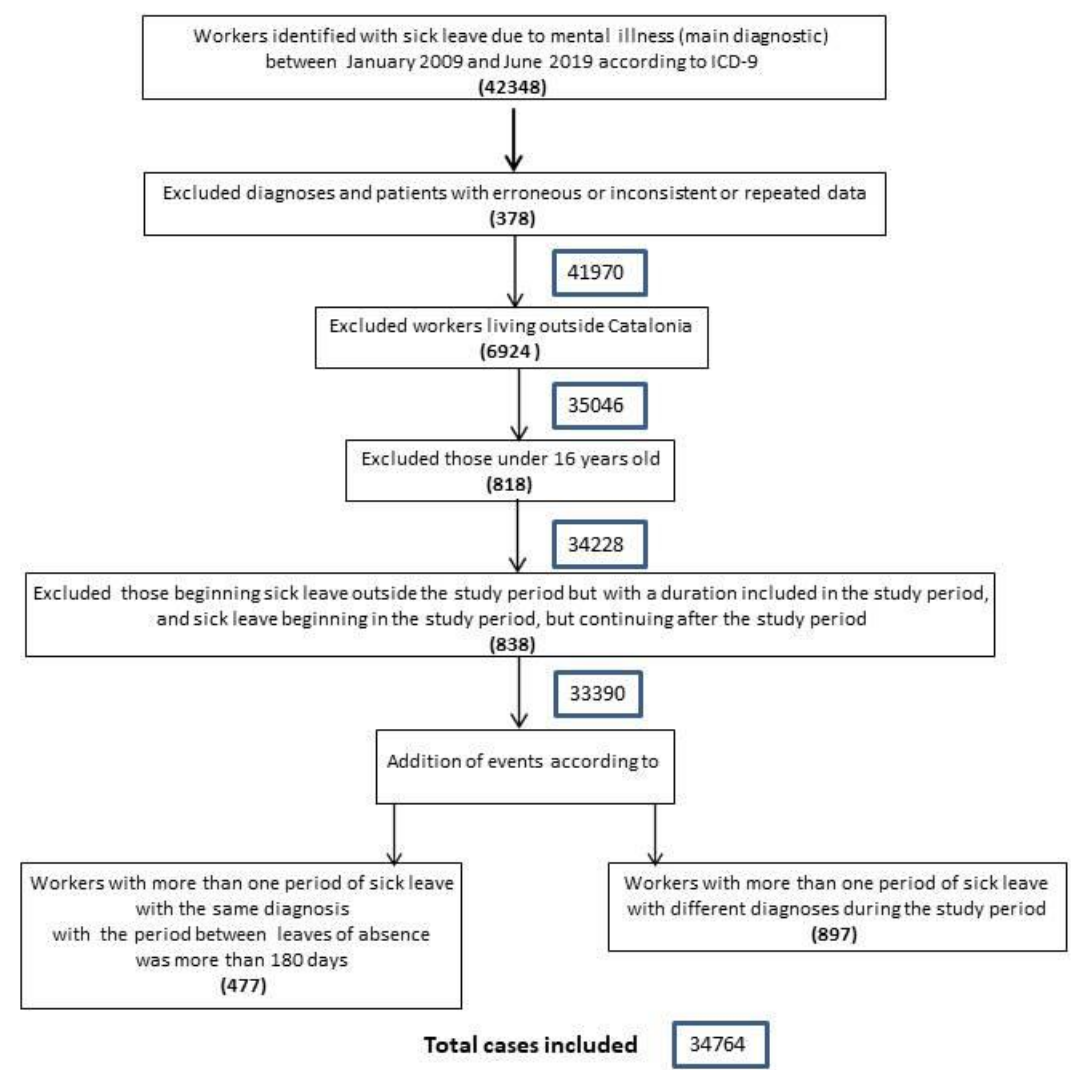

Table 1. Descriptive results of dependent variables, days spent on SL and sociodemographic and employment-related predictive independent variables.

\begin{tabular}{|c|c|c|c|}
\hline \multirow{2}{*}{ Groups of Diseases } & Events & Days spent on SL & Age when began SL \\
\cline { 2 - 4 } & $\mathbf{N}(\%)$ & Mean (SD) & Mean (SD) \\
\hline Schizophrenic disorders & $206(0.6)$ & $163.3(12.5)$ & $38.9(8.7)$ \\
\hline
\end{tabular}




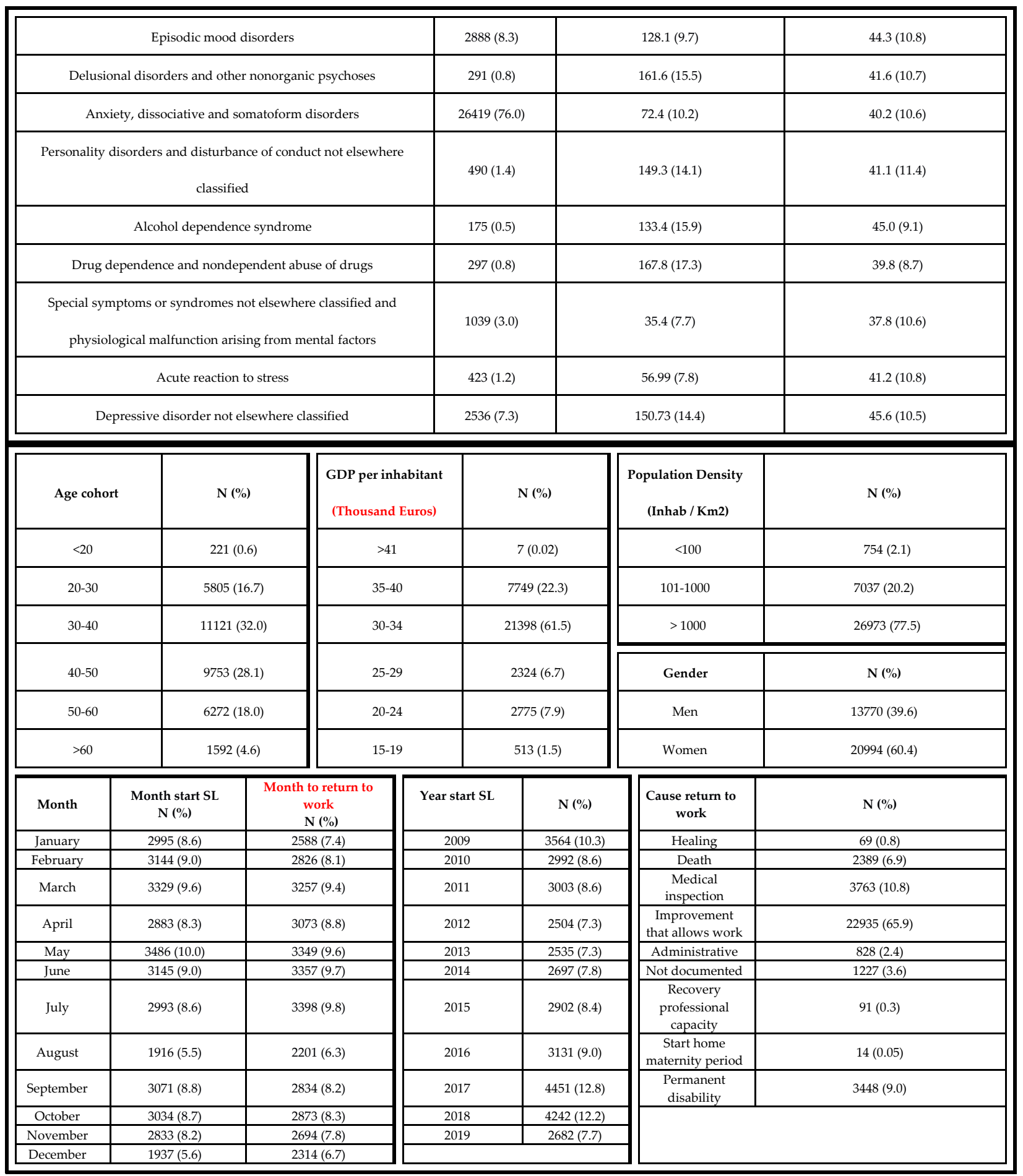

SL: Sick leave

SD: Standard deviation

GDP: Gross domestic product

Meanwhile, March, April, May, June and July were the months with the highest levels of patients returning to work after SL due to mental illness, and August and December were those with the fewest patients returning to work after SL. A progressive decline in the number of SL events due to mental illness was observed in 2009, 2010, 2011, 2012 and 2013, while a progressive increase in the number of SL events due to mental illness was confirmed for the period 2014-19.

Automobile mechanics accounted for the most workers on SL due to mental illness (18.1\%), followed by manufacturing industries (14.2\%), education $(10.2 \%)$, residential nursing care 
activities (9.0\%), health and social service activities (6.4\%), road and rail construction companies $(6.2 \%)$ and taxi drivers $(5.8 \%)$. In the total number of records selected in the years covered by the study, 17,988 cases of illnesses had NOC codes (51.7\% of the total for the years between 2012 and 2018). The results obtained with this variable in the study are only taken from these data. Scientific and intellectual specialists and professionals and support specialists and professionals therefore accounted for $47 \%$ of the total workers.

The mental pathologies with the longest average length of SL were drug dependency and nondependent abuse of drugs with 167.8 days, followed by schizophrenic disorders with 163.35 days, and delusional disorders and other nonorganic psychoses with 161.6 days. The mental illnesses with the shortest SL periods were neurotic disorders (special symptoms or syndromes not elsewhere classified, and physiological dysfunctions due to mental factors and anxiety, dissociative and somatoform disorders).

As for the age of the worker at the time the SL period began, the youngest mean age of the patients was for those with schizophrenic disorders (38.9 years) and drug dependence/non-dependent abuse of drugs (39.8 years), while for episodic mood disorders and depressive disorder not elsewhere classified the patients had an older mean age.

\section{Statistical multivariate logistic and Cox regression model results}

Tables 3-5 present the results of the independent variables that were statistically significant in the statistical multivariate logistic and Cox regression model. Results with high levels of statistical significance $(p \leq 0.01)$ are presented in bold type.

The goodness of fit was reviewed for the categorical data in each regression, obtaining a nonsignificant $p$ value which confirmed the model's goodness of fit. In the multivariate logistic regression models the results were as follows: psychotic disorders: Chi-square of 4.34, $\mathrm{p}$ 0.34; neurotic disorders (anxiety and dissociative and somatoform disorders): Chi-square 1.29, p 0.67; acute reaction to stress: Chi-square 2.25, p 0.64; depressive disorders not elsewhere classified: Chi-square 2.88, p 0.39, personality disorders and behavior alterations not elsewhere classified: Chi-square 2.97, p 0.29; alcohol dependence syndrome: Chi-square 1.89, p 0.66; drug dependence and non-dependent drug abuse,: Chi-square 3.78, p 0.28; special symptoms or syndromes not elsewhere classified and physiological malfunction arising from mental factors: Chi-square 2.03, p 0.48 .

\section{$\underline{\text { Sociodemographic variables }}$}

Table 3 presents the results of the multiple logistic regression statistics for the sociodemographic predictors. The model indicates that various socio-demographic characteristics are associated with several groups of mental diseases.

Table 2. Descriptive results of the predictive economic variables (type of payment, type of social security contributions, NCBA, NOC).

\begin{tabular}{|c|c|c|}
\hline \multicolumn{2}{|c|}{ Factor } & N (\%) \\
\hline \multirow{3}{*}{ Type of payment } & Delegate payment & $26173(75.3)$ \\
\cline { 2 - 3 } & Direct payment & $5266(15.2)$ \\
\cline { 2 - 3 } & $\begin{array}{c}\text { Contract termination during sick } \\
\text { leave }\end{array}$ & $3325(9.6)$ \\
\hline $\begin{array}{c}\text { Type of social security } \\
\text { contributions }\end{array}$ & Self employed & $3859(11.1)$ \\
\cline { 2 - 3 } & General scheme & $30844(88.7)$ \\
\hline
\end{tabular}




\begin{tabular}{|c|c|}
\hline Others & $61(0.2)$ \\
\hline NCBA Groups & $\mathrm{N}(\%)$ \\
\hline No description & $54(0.2)$ \\
\hline Agriculture. forestry and fishing & $51(0.2)$ \\
\hline Construction of roads and railways & $2239(6.2)$ \\
\hline Domestic workers & $228(0.6)$ \\
\hline Extra-territorial bodies and organizations & $7(0.02)$ \\
\hline Financial leasing & $242(0.7)$ \\
\hline Gambling and betting activities & $743(2.0)$ \\
\hline Legal and accounting activities & $234(0.6)$ \\
\hline Health and social service activities & $2341(6.4)$ \\
\hline Manufacturing & $5151(14.2)$ \\
\hline Mining and quarrying & $6(0.02)$ \\
\hline Education & $3709(10.2)$ \\
\hline Other accommodation (host) & $1473(4.1)$ \\
\hline Production of electricity & $6(0.02)$ \\
\hline Public order and safety activities & $1757(4.8)$ \\
\hline Public relations and communication activities & $1429(3.9)$ \\
\hline Renting and leasing of agricultural machinery & $2241(6.2)$ \\
\hline Repair of communication equipment & $1314(3.6)$ \\
\hline Residential nursing care activities & $3247(9.0)$ \\
\hline Software publishing & $678(1.9)$ \\
\hline Taxi operation & $2101(5.8)$ \\
\hline Waste collection. treatment and disposal activities & $429(1.2)$ \\
\hline Wholesale trade of motor vehicle parts and accessories & $6581(18.1)$ \\
\hline NOC Groups & $\mathrm{N}(\%)$ \\
\hline Business management and public administrations & $496(2.7)$ \\
\hline Scientific and intellectual specialists and professionals & $2769(15.4)$ \\
\hline Support specialists and professionals & $5696(31.6)$ \\
\hline Administrative employees & $1938(10.8)$ \\
\hline Restaurant, personal, protection and sales service workers & $2612(14.5)$ \\
\hline Skilled agriculture and fisheries workers & $216(1.2)$ \\
\hline Artisans and skilled workers in manufacturing & $1808(10.1)$ \\
\hline Construction and mining industries & $484(2.7)$ \\
\hline Plant and machinery operators and assemblers & $1725(9.6)$ \\
\hline Unskilled workers & $254(1.4)$ \\
\hline
\end{tabular}

NCBA: National Code of Business Activity, 2009

NOC: National Occupation Code, 1994

Affective disorders due to anxiety and depression and episodic mood disorders are the groups of mental pathologies with the most sociodemographic variables significantly associated with SL, while delusional and personality disorders and alcohol and drug dependence have practically no sociodemographic factors associated with SL. A high population density $(>1,000$ inhabitants $/ \mathrm{km} 2$ ) is positively associated with SL due to affective disorders (anxiety and depression, $\mathrm{p} \leq 0.01)$ compared to regions with a low population density $(<100$ inhabitants $/ \mathrm{km} 2)$, and the wealth of the region is significantly associated with SL in some of the mental pathologies analyzed: the richest regions (GDP per inhabitant: 30-40,000 $€$ ) are a risk factor for absenteeism by workers due to anxiety and acute reaction to stress, while the poorest regions (GDP per inhabitant: $15-25,000 €$ ) are risk factors for SL due to depressive disorders ( $\mathrm{p} \leq 0.01)$. As for gender, significantly positive associations were found in women for anxiety disorders, personality disorders and depression disorders, and in men for drug dependence and non-dependent abuse of drugs.

\section{Employment-related variables}

Schizophrenic disorders, personality disorders, and anxiety states are the pathologies most significantly influenced by the month of onset or end of SL (table 4). Workers with anxiety disorders do not start their SL period in the summer months (June, July, August and September, $p \leq 0.01$ ) to a significant extent, while workers with depressive disorders are positively associated with starting their SL period in that season (July and August). Beginning periods of SL due to personality disorders and conduct disturbances not elsewhere classified is significantly associated with the summer months. 
The year when the SL started has the greatest effect on the association of SL due to mental illness. The likelihood of SL increases significantly among workers with anxiety throughout the period studied. Depression is another pathology with a strong association with a likelihood of SL according to the start year: it increased significantly in 2012-2015 (the years of the economic crisis) ( $p \leq 0.01$ ), while it declined significantly in 2010 and 2016-2019 ( $p \leq 0.01)$.

When anxiety, dissociative and somatoform disorders are considered the baseline of the Cox regression, the symptoms or syndromes not classified elsewhere and physiological disorders arising from mental factors group does not present statistically significant differences for the duration of sick leave, while the other groups of diseases do present these differences. In these mental illness groups, since the HR is less than one, they tend to have shorter SL and these patients therefore tend to return to work earlier than those diagnosed with anxiety disorders.

\section{Economic variables.}

As regards the economic variables (Table 5), according to the type of payment, psychotic disorders, drug dependence and non-dependent abuse of drug and depressive disorders are positively associated with direct payment, while in neurotic pathology groups the association significantly declines among workers receiving direct payment $(p \leq 0.01)$. Self-employed workers had a significantly positive association with anxiety and depressive disorders and drug dependence and non-dependent drug abuse $(p \leq 0.01)$.

The business activity of the companies where the patients on SL due to mental illness worked provided significant results. The probability of SL due to anxiety disorders increases significantly in extra-territorial bodies and organizations and gambling and betting activities, health and social service activities $(p \leq 0.01)$ and education activities. Legal and accounting activities and financial leasing are associated with a high risk of SL due to personality disorders $(p \leq 0.01)$. The probability of SL due to an acute reaction to stress increases in workers involved in communication repairs. SL in schizophrenic disorders and alcohol dependence syndrome are positively associated with waste collection, treatment and disposal activities. Increase of depression disorders are associated with health and social service activities and education $(p \leq 0.01)$ and residential nursing care activities. Finally, few significant results were observed for the NOC. In specific terms, the probability of drug dependence and nondependent abuse of drugs increases significantly among restaurant, personal, protection and sales service workers.

\section{Discussion}

A report based on data published by the Spanish Institute of Statistics regarding absenteeism and its magnitude in the labor market in the first quarter of 2019 indicates that 267,000 people did not go to work without being on sick leave every day, and an average of 747,000 workers were on temporary sick leave [26].

Table 3. Multivariate logistic regression model of sociodemographic variables.

\begin{tabular}{|c|c|c|c|c|c|c|c|c|c|c|}
\hline & $\begin{array}{c}\text { Schizophrenic } \\
\text { disorders }\end{array}$ & $\begin{array}{l}\text { Episodic mood } \\
\text { disorders }\end{array}$ & $\begin{array}{c}\text { Delusional } \\
\text { disorders } \\
\text { and other } \\
\text { nonorganic } \\
\text { psychoses }\end{array}$ & $\begin{array}{c}\text { Anxiety, } \\
\text { dissociative } \\
\text { and } \\
\text { somatoform } \\
\text { disorders }\end{array}$ & $\begin{array}{c}\text { Personality } \\
\text { disorders and } \\
\text { disturbance } \\
\text { of conduct } \\
\text { not elsewhere } \\
\text { classified }\end{array}$ & $\begin{array}{c}\text { Alcohol } \\
\text { dependenc } \\
\text { e syndrome }\end{array}$ & $\begin{array}{c}\text { Drug } \\
\text { dependence } \\
\text { and } \\
\text { nondependent } \\
\text { abuse of } \\
\text { drugs }\end{array}$ & $\begin{array}{c}\text { Special } \\
\text { symptoms or } \\
\text { syndromes } \\
\text { not elsewhere } \\
\text { classified and } \\
\text { physiological }\end{array}$ & $\begin{array}{l}\text { Acute } \\
\text { reaction to } \\
\text { stress }\end{array}$ & $\begin{array}{c}\text { Depressive } \\
\text { disorder } \\
\text { not } \\
\text { elsewhere } \\
\text { classified }\end{array}$ \\
\hline
\end{tabular}




\begin{tabular}{|c|c|c|c|c|c|c|c|c|c|c|}
\hline & & & & & & & & $\begin{array}{l}\text { malfunction } \\
\text { arising from } \\
\text { mental factors }\end{array}$ & & \\
\hline $\begin{array}{c}\text { Population } \\
\text { density by } \\
\text { Region } \\
\text { (inhab/km2) }\end{array}$ & $\begin{array}{l}\text { OR (CI 95\%) } \\
\text { p value }\end{array}$ & $\begin{array}{l}\text { OR (CI 95\%) } \\
\text { p value }\end{array}$ & $\begin{array}{l}\text { OR (CI } 95 \%) \\
\text { p value }\end{array}$ & $\begin{array}{c}\text { OR (CI } 95 \%) \\
\text { p value }\end{array}$ & $\begin{array}{c}\text { OR (CI } 95 \%) \\
\text { p value }\end{array}$ & $\begin{array}{c}\text { OR (CI 95\%) } \\
\text { p value }\end{array}$ & $\begin{array}{l}\text { OR (CI } 95 \%) \\
\text { p value }\end{array}$ & $\begin{array}{l}\text { OR (CI 95\%) } \\
\text { p value }\end{array}$ & $\begin{array}{c}\text { OR (CI } 95 \%) \\
\text { p value }\end{array}$ & $\begin{array}{l}\text { OR (CI 95\%) } \\
\text { p value }\end{array}$ \\
\hline$<100$ & & & & & & & & & $\begin{array}{c}2.34(1.88-2.76) \\
0.041\end{array}$ & $\begin{array}{c}3.99(3.54-4.423) \\
0.077\end{array}$ \\
\hline $101-1000$ & $\begin{array}{c}2.87(2.37-3.08) \\
0.099\end{array}$ & $\begin{array}{c}0.36(0.29-0.42) \\
0.010\end{array}$ & $\begin{array}{c}0.21(0.18-0.25) \\
0.013\end{array}$ & $\begin{array}{c}1.30(1.09-1.49) \\
0.021\end{array}$ & $\begin{array}{c}0.44(0.27-0.88) \\
0.140\end{array}$ & $\begin{array}{c}0.98(0.87-1.24) \\
0.067\end{array}$ & $\begin{array}{c}.49(2.68-3.97) \\
0.322 \\
\end{array}$ & $\begin{array}{c}1.65(1.23-2.99) \\
0.765\end{array}$ & & $\begin{array}{c}0.27(0.23-0.31) \\
0.010\end{array}$ \\
\hline $\begin{array}{l}>1000 \\
\text { (high) }\end{array}$ & $\begin{array}{c}1.92(1.77-2.12) \\
0.021\end{array}$ & & $\begin{array}{c}1.88(1.57-2.08) \\
0.075\end{array}$ & $\begin{array}{c}1.89(1.67-1.98) \\
0.009\end{array}$ & $\begin{array}{c}0.39(0.33-0.42) \\
0.025\end{array}$ & $\begin{array}{c}2.78(2.14-2.97) \\
0.289\end{array}$ & $\begin{array}{c}2.77(2.27-2.98) \\
0.083\end{array}$ & $\begin{array}{c}1.77(1.23-1.98) \\
0.089\end{array}$ & $\begin{array}{c}2.73(2.49-2.88) \\
0.016\end{array}$ & $\begin{array}{c}1.45(1.38-1.54) \\
\mathbf{0 . 0 1 0}\end{array}$ \\
\hline \multicolumn{11}{|l|}{$\begin{array}{l}\text { GDP per } \\
\text { inhabitant by } \\
\text { Region } \\
\text { (Thousand } \\
\text { Euros) }\end{array}$} \\
\hline \multicolumn{11}{|l|}{$>41$} \\
\hline $35-40$ & $\begin{array}{c}2.41(1.94-2.70) \\
0.088 \\
\end{array}$ & $\begin{array}{c}8.61(6.88-9.21) \\
0.145 \\
\end{array}$ & $\begin{array}{c}5.75(4.38-6.49) \\
0.099 \\
\end{array}$ & $\begin{array}{c}1.09(0.96-1.16) \\
\mathbf{0 . 0 0 9} \\
\end{array}$ & $\begin{array}{c}2.88(2.42-3.27) \\
0.067 \\
\end{array}$ & $\begin{array}{c}1.92(1.76-2.36) \\
0.073 \\
\end{array}$ & $\begin{array}{c}2.88(2.22-3.45) \\
0.113 \\
\end{array}$ & $\begin{array}{c}0.87(0.56-1.24) \\
0.082 \\
\end{array}$ & $\begin{array}{c}1.96(1.88-2.07) \\
0.018 \\
\end{array}$ & $\begin{array}{c}3.78(3.24-4.45) \\
0.162 \\
\end{array}$ \\
\hline $30-34$ & $\begin{array}{c}0.66(0.38-0.88) \\
0.061\end{array}$ & $\begin{array}{c}2.73(2.56-2.89) \\
0.014\end{array}$ & $\begin{array}{c}2.18(1.72-2.67) \\
0.087\end{array}$ & $\begin{array}{c}1.52(1.16-1.76) \\
0.063\end{array}$ & $\begin{array}{c}3.18(2.72-3.46) \\
0.213\end{array}$ & $\begin{array}{c}.87(1.66-2.24) \\
0.085\end{array}$ & $\begin{array}{c}0.94(0.58-1.31) \\
0.165\end{array}$ & $\begin{array}{c}2.16(1.92-2.64) \\
0.110\end{array}$ & $\begin{array}{c}0.63(0.58-0.69) \\
0.032\end{array}$ & $\begin{array}{c}1.84(1.57-2.31) \\
0.210\end{array}$ \\
\hline $25-29$ & $\begin{array}{c}1.19(0.93-1.54) \\
0.182\end{array}$ & $\begin{array}{c}0.63(0.58-0.69) \\
0.018\end{array}$ & $\begin{array}{c}3.47(3.10-3.94) \\
0.071\end{array}$ & $\begin{array}{c}2.38(2.01-2.28) \\
0.082\end{array}$ & $\begin{array}{c}2.71(2.36-2.93) \\
0.070\end{array}$ & $\begin{array}{c}0.32(0.16-0.69) \\
0.073\end{array}$ & $\begin{array}{c}0.63(0.46-0.89) \\
0.067\end{array}$ & $\begin{array}{c}0.86(0.52-1.17) \\
0.073\end{array}$ & $\begin{array}{c}2.34(2.21-2.48) \\
0.034\end{array}$ & $\begin{array}{l}0.68(0.27-0.96) \\
0.114\end{array}$ \\
\hline $20-24$ & $\begin{array}{c}0.88(0.42-1.37) \\
0.087\end{array}$ & $\begin{array}{c}3.92(3.36-4.56) \\
0.173\end{array}$ & $\begin{array}{c}2.18(1.182-2.45) \\
0.083\end{array}$ & $\begin{array}{c}2.83(2.56-3.304) \\
0.064\end{array}$ & $\begin{array}{l}1.41(1.03-1.58) \\
0.090\end{array}$ & $\begin{array}{c}1.41(1.19-1.62) \\
0.078\end{array}$ & $\begin{array}{l}0.75(0.38-0.96) \\
0.211\end{array}$ & $\begin{array}{c}2.08(1.87-2.42) \\
0.072\end{array}$ & $\begin{array}{c}2.76(2.488-2.99) \\
0.071\end{array}$ & $\begin{array}{l}1.45(1.33-1.59) \\
0.009\end{array}$ \\
\hline 15-19 & $\begin{array}{c}0.29(0.10-0.47) \\
0.072 \\
\end{array}$ & $\begin{array}{c}0.73(0.47-0.95) \\
0.073 \\
\end{array}$ & $\begin{array}{c}1.82(1.66-2.29) \\
0.061 \\
\end{array}$ & $\begin{array}{c}1.91(1.76-2.38) \\
0.078 \\
\end{array}$ & $\begin{array}{c}1.23(1.09-1.58) \\
0.172 \\
\end{array}$ & $\begin{array}{c}1.33(1.09-2.94) \\
0.187 \\
\end{array}$ & $\begin{array}{c}2.63(2.42-2.79) \\
0.072 \\
\end{array}$ & $\begin{array}{c}0.26(0.10-0.47) \\
0.072 \\
\end{array}$ & $\begin{array}{c}2.49(2.03-2.59) \\
0.068 \\
\end{array}$ & $\begin{array}{c}2.09(1.89-2.28) \\
0.022 \\
\end{array}$ \\
\hline \multicolumn{11}{|l|}{$\begin{array}{c}\text { Age cohort } \\
\text { (Years) }\end{array}$} \\
\hline$<20$ & $\begin{array}{c}0.67(0.40-0.84) \\
0.061\end{array}$ & $\begin{array}{c}1.58(1.21-1.82) \\
0.062\end{array}$ & $\begin{array}{c}1.71(1.16-1.199) \\
0.119\end{array}$ & $\begin{array}{c}1.32(1.06-1.46) \\
0.063\end{array}$ & $\begin{array}{l}1.29(1.00-1.47) \\
0.072\end{array}$ & $\begin{array}{l}0.53(0.47-0.59) \\
0.013\end{array}$ & $\begin{array}{c}0.12(0.09-0.15) \\
0.031\end{array}$ & $\begin{array}{c}0.11(0.08-0.14) \\
0.012\end{array}$ & $\begin{array}{c}1.30(0.92-1.75) \\
0.093\end{array}$ & $\begin{array}{c}.33(1.06-1.51) \\
0.071\end{array}$ \\
\hline $20-29$ & $\begin{array}{l}2.13(2.06-2.269) \\
0.087\end{array}$ & $\begin{array}{c}2.11(1.98-2.23) \\
0.010\end{array}$ & $\begin{array}{c}0.14(0.10-0.19) \\
0.015\end{array}$ & $\begin{array}{c}1.62(1.34-1.98) \\
0.073\end{array}$ & $\begin{array}{l}1.33(1.106-1.79) \\
0.097\end{array}$ & $\begin{array}{c}2.56(2.17-2.92) \\
0.089\end{array}$ & $\begin{array}{c}0.60(0.32-0.97) \\
0.063\end{array}$ & $\begin{array}{c}0.19(0.15-0.23) \\
0.012\end{array}$ & $\begin{array}{c}1.44(1.08-1.161) \\
0.065\end{array}$ & $\begin{array}{c}3.94(3.55-4.23) \\
0.015\end{array}$ \\
\hline 30-39 & $\begin{array}{c}0.10(0.07-0.12) \\
0.024\end{array}$ & $\begin{array}{c}2.49(2.33-2.59) \\
0.017\end{array}$ & $\begin{array}{c}0.41(0.36-0.45) \\
0.023\end{array}$ & $\begin{array}{c}0.56(0.50-0.62) \\
0.014\end{array}$ & $\begin{array}{c}3.16(2.82-3.54) \\
0.090\end{array}$ & $\begin{array}{c}2.44(2.18-2.98) \\
0.115\end{array}$ & $\begin{array}{c}2.44(2.08-2.97) \\
0.165\end{array}$ & $\begin{array}{c}0.36(0.31-0.40) \\
0.024\end{array}$ & $\begin{array}{c}2.33(2.06-2.279) \\
0.097\end{array}$ & $\begin{array}{c}3.46(3.22-3.54) \\
0.027\end{array}$ \\
\hline $40-49$ & $\begin{array}{c}0.10(0.08-0.11) \\
0.012\end{array}$ & $\begin{array}{c}2.05(1.96-2.12) \\
0.011\end{array}$ & $\begin{array}{c}.84(0.57-1.09) \\
0.710\end{array}$ & $\begin{array}{c}0.63(0.54-0.69) \\
0.013\end{array}$ & $\begin{array}{c}0.39(0.12-0.57) \\
0.063\end{array}$ & $\begin{array}{c}.33(1.06-01.79) \\
0.187\end{array}$ & $\begin{array}{c}.33(0.06-0.59) \\
0.077\end{array}$ & $\begin{array}{c}0.41(0.35-0.46) \\
0.032\end{array}$ & $\begin{array}{c}0.55(0.28-0.96) \\
0.091\end{array}$ & $\begin{array}{c}2.29(2.12-2.38) \\
0.010\end{array}$ \\
\hline $50-59$ & $\begin{array}{c}0.50(0.43-0.54) \\
0.050\end{array}$ & $\begin{array}{c}1.51(1.44-1.61) \\
0.010\end{array}$ & $\begin{array}{c}1.68(1.37-1.91) \\
0.084\end{array}$ & $\begin{array}{c}0.76(0.69-0.83) \\
0.013 \\
\end{array}$ & $\begin{array}{c}2.19(1.87-2.42) \\
0.142 \\
\end{array}$ & $\begin{array}{c}0.51(0.28-0.96) \\
0.211\end{array}$ & $\begin{array}{c}0.95(0.68-1.26) \\
0.091\end{array}$ & $\begin{array}{c}2.43(2.19-2.79) \\
0.072 \\
\end{array}$ & $\begin{array}{c}0.38(0.12-0.35) \\
0.063\end{array}$ & $\begin{array}{c}1.64(1.54-1.71) \\
0.012\end{array}$ \\
\hline \multicolumn{11}{|l|}{$>60$} \\
\hline \multicolumn{11}{|l|}{ Gender } \\
\hline Women & $\begin{array}{c}1.52(1.26-1.86) \\
0.163\end{array}$ & $\begin{array}{c}2.94(2.35-3.23) \\
0.085\end{array}$ & $\begin{array}{c}0.76(0.23-0.98) \\
0.181\end{array}$ & $\begin{array}{c}.45(3.12-3.77) \\
0.021\end{array}$ & $\begin{array}{c}1.38(1.22-1.48) \\
0.042\end{array}$ & $\begin{array}{c}0.89(0.60-1.17) \\
0.092\end{array}$ & & $\begin{array}{c}2.54(2.26-2.91) \\
0.084\end{array}$ & $\begin{array}{c}.14(2.85-3.83) \\
0.115\end{array}$ & $\begin{array}{c}2.87(2.77-2.98) \\
0.020\end{array}$ \\
\hline Men & & & & & & & $\begin{array}{c}1.78(1.69-1.90) \\
0.033\end{array}$ & & & \\
\hline
\end{tabular}

GDP: Gross domestic product. Bold type: High statistical significance (P value less than 0.01). Italic type: P value less than 0.05 .

Reference categories: Population density by region: $<100$ (schizophrenic disorders, episodic mood disorders, delusional disorders and other nonorganic psychoses, anxiety, dissociative and somatoform disorders, personality disorders and disturbance of conduct not elsewhere classified, alcohol dependence syndrome, drug dependence and nondependent abuse of drugs and special symptoms or syndromes not elsewhere classified and physiological malfunction arising from mental factors); 101-1000 (acute reaction to stress); >1000 (high) (episodic mood disorders). GDP per inhabitant: $>41$ thousands of euros (for all Models). Age cohort: $>60$ years (for all Models). Gender: man (schizophrenic disorders, episodic mood disorders, delusional disorders and other nonorganic psychoses, anxiety, dissociative and somatoform disorders, personality disorders and disturbance of conduct not elsewhere classified and depressive disorder not elsewhere classified, alcohol dependence syndrome, special symptoms or syndromes not elsewhere classified and physiological malfunction arising from mental factors, acute reaction to stress and depressive disorder not elsewhere classified); women (drug dependence and nondependent abuse of drugs).

These data alarm on the significant expense that this labor situation supposes for companies, mutual insurance companies, the State and the workers themselves, which, being perfectly justified, does not exempt them from falling on shadows of rentier absenteeism denounced numerous times in different estates: the existence of the Medical Evaluation Courts give proof of this. The fact that this absenteeism exists is based by the business confederations in the direct relationship with the improvement of the economy and for two reasons: the less economic crisis the greater the number of hired workers (statistical data), and less fear of losing the job of work

Table 4. Regression models of employment-related variables.

Multivariate logistic regression model of the variable year of SL and month of start of SL and return to work

\begin{tabular}{|c|c|c|c|c|c|c|c|c|c|c|}
\hline & $\begin{array}{c}\text { Schizophrenic } \\
\text { disorders }\end{array}$ & $\begin{array}{l}\text { Episodic } \\
\text { mood } \\
\text { disorders }\end{array}$ & $\begin{array}{c}\text { Delusional } \\
\text { disorders } \\
\text { and other } \\
\text { nonorganic } \\
\text { psychoses }\end{array}$ & $\begin{array}{c}\text { Anxiety, } \\
\text { dissociative } \\
\text { and } \\
\text { somatoform } \\
\text { disorders }\end{array}$ & 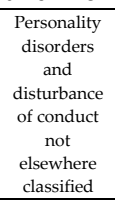 & $\begin{array}{l}\text { Alcohol } \\
\text { dependence } \\
\text { syndrome }\end{array}$ & $\begin{array}{c}\text { Drug } \\
\text { dependence } \\
\text { and } \\
\text { nondependent } \\
\text { abuse of } \\
\text { drugs }\end{array}$ & $\begin{array}{c}\text { Symptoms or } \\
\text { syndromes } \\
\text { not elsewhere } \\
\text { classified and } \\
\text { physiological } \\
\text { malfunction } \\
\text { arising from } \\
\text { mental factors }\end{array}$ & $\begin{array}{l}\text { Acute } \\
\text { reaction to } \\
\text { stress }\end{array}$ & $\begin{array}{c}\text { Depressive } \\
\text { disorder not } \\
\text { elsewhere } \\
\text { classified }\end{array}$ \\
\hline Year to begin SL & $\begin{array}{c}\text { OR (CI 95\%) } \\
\text { p value }\end{array}$ & $\begin{array}{c}\text { OR (CI 95\%) } \\
\text { p value }\end{array}$ & $\begin{array}{c}\text { OR (CI 95\%) } \\
\text { p value }\end{array}$ & $\begin{array}{c}\text { OR (CI 95\%) } \\
\text { p value }\end{array}$ & $\begin{array}{c}\text { OR (CI 95\%) } \\
\text { p value }\end{array}$ & $\begin{array}{c}\text { OR (CI } 95 \%) \\
\text { p value }\end{array}$ & $\begin{array}{c}\text { OR (CI 95\%) } \\
\text { p value }\end{array}$ & $\begin{array}{c}\text { OR (CI } 95 \%) \\
\text { p value }\end{array}$ & $\begin{array}{l}\text { OR (CI } \\
95 \%) \\
\text { p value }\end{array}$ & $\begin{array}{c}\text { OR (CI 95\%) } \\
\text { p value }\end{array}$ \\
\hline 2009 & & $\begin{array}{c}0.39(0.32-0.44) \\
0.012\end{array}$ & & $\begin{array}{c}2.47(2.22-2.57) \\
0.014\end{array}$ & $\begin{array}{c}0.12(0.09-0.14) \\
0.010\end{array}$ & & & & $\begin{array}{c}0.13(0.01-0.15) \\
0.010\end{array}$ & \\
\hline 2010 & $2.38(2.18-2.49)$ & $0.49(0.40-0.55)$ & $1.04(0.88-1.35)$ & 1.55 (1.29-1.67) & $0.46(0.38-0.51)$ & $0.83(0.57-0.97)$ & $0.33(0.17-0.59)$ & $2.37(2.17-2.48)$ & & $0.68(0.59-0.74)$ \\
\hline
\end{tabular}




\begin{tabular}{|c|c|c|c|c|c|c|c|c|c|c|c|}
\hline & & 0.050 & 0.012 & 0.081 & 0.013 & 0.011 & 0.063 & 0.073 & 0.010 & & 0.012 \\
\hline \multicolumn{2}{|c|}{2011} & $\begin{array}{c}0.63(0.37-0.89) \\
0.113\end{array}$ & $\begin{array}{c}0.47(0.40-0.54) \\
0.011\end{array}$ & $\begin{array}{c}0.58(0.51-0.62) \\
0.042\end{array}$ & $\begin{array}{c}1.71(1.66-1.80) \\
\mathbf{0 . 0 1 0}\end{array}$ & $\begin{array}{c}0.32(0.26-0.39) \\
0.013\end{array}$ & $\begin{array}{c}1.59(1.37-1.72) \\
0.071\end{array}$ & $\begin{array}{c}2.05(1.87-2.94) \\
0.079\end{array}$ & $\begin{array}{c}2.48(2.29-2.61) \\
0.012\end{array}$ & $\begin{array}{c}0.38(0.32-0.47) \\
0.041\end{array}$ & $\begin{array}{c}1.07(0.78-1.45) \\
0.231\end{array}$ \\
\hline \multicolumn{2}{|c|}{2012} & $\begin{array}{c}1.56(1.19-1.92) \\
0.089\end{array}$ & $\begin{array}{c}0.52(0.44-0.60) \\
0.0002\end{array}$ & $\begin{array}{c}1.37 \text { (1.18-1.65) } \\
0.071\end{array}$ & $\begin{array}{c}1.65(1.49-1.71) \\
0.014\end{array}$ & $\begin{array}{c}0.25(0.20-0-30) \\
0.015\end{array}$ & $\begin{array}{c}2.14(1.92-2.31) \\
0.135\end{array}$ & $\begin{array}{c}2.44(2.18-2.91) \\
0.119\end{array}$ & $\begin{array}{c}1.88(1.69-1.99) \\
0.014\end{array}$ & $\begin{array}{c}0.25(0.21-0.29) \\
0.014\end{array}$ & $\begin{array}{c}1.89(1.71-1.99) \\
0.024\end{array}$ \\
\hline \multicolumn{2}{|c|}{2013} & $\begin{array}{c}2.44(2.18-2.91) \\
0.115\end{array}$ & $\begin{array}{c}0.44(0.40-0.50) \\
0.010\end{array}$ & $\begin{array}{c}0.67(0.62-0.73) \\
0.033\end{array}$ & $\begin{array}{c}1.61(1.54-1.67) \\
\mathbf{0 . 0 1 0}\end{array}$ & $\begin{array}{c}0.33(0.28-0.39) \\
0.013\end{array}$ & $\begin{array}{c}1.33(1.06-1.79) \\
0.087\end{array}$ & $\begin{array}{c}1.35(1.03-01.69) \\
0.082\end{array}$ & $\begin{array}{c}1.80(1.72-1.91 \\
0.010\end{array}$ & $\begin{array}{c}0.50(0.39-0.58) \\
0.043\end{array}$ & $\begin{array}{c}1.42(1.38-1.47) \\
\mathbf{0 . 0 1 0}\end{array}$ \\
\hline \multicolumn{2}{|c|}{2014} & $\begin{array}{c}3.33(3.08-3.79) \\
0.083\end{array}$ & $\begin{array}{c}0.52(0.44-0.58) \\
0.011\end{array}$ & $\begin{array}{c}0.44(0.39 .0-50) \\
0.046\end{array}$ & $\begin{array}{c}1.37(1.28-1.50) \\
0.009\end{array}$ & $\begin{array}{c}0.48(0.44-0-54) \\
0.014\end{array}$ & $\begin{array}{c}0.76(0.43-0.89) \\
0.073\end{array}$ & $\begin{array}{c}0.93(0.77-1.39) \\
0.213\end{array}$ & $\begin{array}{c}1.72(1.63-1.80) \\
0.013\end{array}$ & $\begin{array}{c}0.38(0.33-0.41) \\
0.011\end{array}$ & $\begin{array}{c}2.26(2.08-2.33) \\
0.009\end{array}$ \\
\hline \multicolumn{2}{|c|}{2015} & $\begin{array}{c}1.57(1.38-1.85) \\
0.061\end{array}$ & $\begin{array}{c}0.88(0.78-0.96) \\
0.023\end{array}$ & $\begin{array}{c}0.48(0.41-0.54) \\
0.014\end{array}$ & $\begin{array}{c}1.22(1-08-1.32) \\
0.009\end{array}$ & $\begin{array}{c}0.32(0.26-0.45) \\
0.014\end{array}$ & $\begin{array}{c}2.96(2.77-3.22) \\
0.076\end{array}$ & $\begin{array}{c}2.26(1.97-2.42) \\
0.069\end{array}$ & $\begin{array}{c}1.99(1.82-2.12) \\
0.012\end{array}$ & $\begin{array}{c}0.30(0.22-0.39) \\
0.010\end{array}$ & $\begin{array}{c}1.42(1.33-1.149) \\
0.010\end{array}$ \\
\hline \multicolumn{2}{|c|}{2016} & $\begin{array}{c}2.12(1.97-2.23) \\
0.032\end{array}$ & $\begin{array}{c}1.27(1.50-1.45) \\
0.081\end{array}$ & $\begin{array}{c}0.59(0.37-0.99) \\
0.113\end{array}$ & $\begin{array}{c}1.21(2.12-2.29) \\
0.011\end{array}$ & $\begin{array}{c}0.19(0.12-0.23) \\
0.012\end{array}$ & $\begin{array}{c}2.24(2.02-2.51) \\
0.215\end{array}$ & $\begin{array}{c}2.74(2.48-2.98) \\
0.110\end{array}$ & $\begin{array}{c}1.65(1.48-1.76) \\
0.010\end{array}$ & $\begin{array}{c}0.30(0.22-0.37) \\
0.013\end{array}$ & $\begin{array}{c}0.70(0.58-0.81) \\
0.015\end{array}$ \\
\hline \multicolumn{2}{|c|}{2017} & $\begin{array}{c}0.83(0.42-153) \\
0.213\end{array}$ & & $\begin{array}{c}2.16(1.97-2.52) \\
0.089\end{array}$ & $\begin{array}{c}1.32(1.24-1.39) \\
0.014\end{array}$ & $\begin{array}{c}0.33(0.36-0.40) \\
0.012\end{array}$ & $\begin{array}{c}0.41(0.16-0.59) \\
0.072\end{array}$ & $\begin{array}{c}1.73(1.46-01.99) \\
0.077\end{array}$ & $\begin{array}{c}1.89(1.76-1.91) \\
0.015\end{array}$ & $\begin{array}{c}0.44(0.38-0.51) \\
0.015\end{array}$ & $\begin{array}{c}0.55(0.50-0.61) \\
0.012\end{array}$ \\
\hline \multicolumn{2}{|c|}{2018} & $\begin{array}{c}2.26(2.07-2.54) \\
0.072\end{array}$ & $\begin{array}{c}1.52(1.44-1.60) \\
0.015\end{array}$ & $\begin{array}{c}2.14(2.01-2.71) \\
0.135\end{array}$ & $\begin{array}{c}1.21(1.15-1.30) \\
0.023\end{array}$ & $\begin{array}{c}0.32(0.24-0.38) \\
0.031\end{array}$ & $\begin{array}{c}2.67(2.48-2.78) \\
0.071\end{array}$ & $\begin{array}{c}0.61(0.48-0.85) \\
0.131\end{array}$ & $\begin{array}{c}1.42(1.34-1.48) \\
0.013\end{array}$ & $\begin{array}{c}0.33(0.26-0.39) \\
0.017\end{array}$ & $\begin{array}{c}0.56(0.47-0.62) \\
0.009\end{array}$ \\
\hline \multicolumn{2}{|c|}{2019} & $\begin{array}{c}2.04(1.88-2.41) \\
0.165\end{array}$ & $\begin{array}{c}1.37(128-1.43) \\
0.024\end{array}$ & $\begin{array}{c}1.66(1.43-1.88) \\
0.081\end{array}$ & & & $\begin{array}{c}1.27(1.08-1.44) \\
0.077\end{array}$ & $\begin{array}{c}1.88(1.58-2.05) \\
0.121\end{array}$ & $\begin{array}{c}1.59(1.48-1.66) \\
0.012\end{array}$ & $\begin{array}{c}0.55(0.48-0.66) \\
0.011\end{array}$ & $\begin{array}{c}0.57(0.51-0.66) \\
\mathbf{0 . 0 1 0}\end{array}$ \\
\hline \multicolumn{12}{|c|}{$\begin{array}{c}\text { Month of SL } \\
\text { Month of RTW }\end{array}$} \\
\hline \multirow{2}{*}{ January } & SL & $\begin{array}{c}2.96(2.67-3.54) \\
0.172 \\
\end{array}$ & $\begin{array}{c}1.82(1.44-2.10) \\
0.075 \\
\end{array}$ & $\begin{array}{c}4.14(3.61-4.51) \\
0.175 \\
\end{array}$ & $\begin{array}{c}1.81(1.45-2.31) \\
0.093 \\
\end{array}$ & $\begin{array}{c}1.32(1.04-01.68) \\
0.081\end{array}$ & $\begin{array}{c}1.67(1.58-1.75) \\
0.031\end{array}$ & $\begin{array}{c}0.82(0.66-1.05) \\
0.074\end{array}$ & $\begin{array}{c}2.16(1.77-2.32) \\
0.088 \\
\end{array}$ & $\begin{array}{c}.26(3.07-3.72) \\
0.068 \\
\end{array}$ & $\begin{array}{c}1.19(1.02-1.52) \\
0.072 \\
\end{array}$ \\
\hline & RTW & & & & & & & & & & \\
\hline \multirow{2}{*}{ February } & SL & $\begin{array}{l}0.78(0.59-0.97) \\
0.112\end{array}$ & $\begin{array}{l}3.93(3.67-4.39) \\
0.163\end{array}$ & $\begin{array}{l}0.57(0.39-0.73) \\
0.076\end{array}$ & $\begin{array}{l}1.24(1.09-1-50) \\
0.076\end{array}$ & $\begin{array}{c}0.44(0.31-0.58) \\
0.066\end{array}$ & $\begin{array}{c}2.66(2.44-2.71) \\
0.02\end{array}$ & $\begin{array}{l}3.26(3.09-3.55) \\
0.079\end{array}$ & $\begin{array}{c}0.86(0.67-0.99) \\
0.060\end{array}$ & $\begin{array}{l}4.66(4.399-4.94) \\
0.092\end{array}$ & $\begin{array}{l}2.98(2.77-3.39) \\
0.050\end{array}$ \\
\hline & RTW & $\begin{array}{c}1.07(0.88-1.33) \\
0.131\end{array}$ & $\begin{array}{c}1.26(0.96-1.42) \\
0.063\end{array}$ & $\begin{array}{c}0.71(0.54-0.94) \\
0.064\end{array}$ & $\begin{array}{c}0.98(0.73-1.14) \\
0.074\end{array}$ & $\begin{array}{c}0.77(0.51-0.94) \\
0.074\end{array}$ & $\begin{array}{c}0.99(0.71-1.26) \\
0.083\end{array}$ & $\begin{array}{l}5.44(5.28-5.71) \\
0.195\end{array}$ & $\begin{array}{c}1.88(1.67-2.02) \\
0.079\end{array}$ & $\begin{array}{c}3.07(2.75-2.35) \\
0.091\end{array}$ & $\begin{array}{c}0.93(0.77-1.29) \\
0.173\end{array}$ \\
\hline \multirow{2}{*}{ March } & SL & $\begin{array}{c}2.77(2.47-2.98) \\
0.012\end{array}$ & $\begin{array}{c}\begin{array}{c}2.54(2.18-2.88) \\
0.109\end{array} \\
\end{array}$ & $\begin{array}{c}0.77(0.57-0.93) \\
0.093\end{array}$ & $\begin{array}{c}0.79(0.57-0.88) \\
0.063\end{array}$ & $\begin{array}{c}0.52(0.36-0.79) \\
0.083\end{array}$ & $\begin{array}{c}1.82(1.56-1.94) \\
0.069\end{array}$ & $\begin{array}{c}.49(3.28-3.88) \\
0.093\end{array}$ & $\begin{array}{c}2.04(1.82-2.25) \\
0.165\end{array}$ & $\begin{array}{c}2.51(2.29-2.82) \\
0.079\end{array}$ & $\begin{array}{c}1.66(1.49-1.82) \\
0.077\end{array}$ \\
\hline & RTW & $\begin{array}{c}.53(3.29-3.80) \\
0.099\end{array}$ & $\begin{array}{c}0.53(0.36-0.59) \\
0.071\end{array}$ & $\begin{array}{c}2.89(2.66-3.07) \\
0.063\end{array}$ & $\begin{array}{c}4.38(4.08-4.61) \\
0.150\end{array}$ & $\begin{array}{c}2.74(2.59-3.02) \\
0.289\end{array}$ & $\begin{array}{c}2.61(2.40-2.89) \\
0.059 \\
\end{array}$ & $\begin{array}{c}2.57(2.28-2.79) \\
0.071\end{array}$ & $\begin{array}{c}1.73(1.56-01.91) \\
0.077 \\
\end{array}$ & $\begin{array}{c}2.94(2.68-3.33) \\
0.095 \\
\end{array}$ & $\begin{array}{c}2.14(1.95-2.41) \\
0.165 \\
\end{array}$ \\
\hline \multirow{2}{*}{ April } & SL & $\begin{array}{c}1.44(1.23-1.71) \\
0.105 \\
\end{array}$ & $\begin{array}{c}0.86(0.59-0.94) \\
0.066\end{array}$ & $\begin{array}{c}2.58(2.36-2.73) \\
0.070\end{array}$ & $\begin{array}{c}2.43(2.27-2.89) \\
0.313\end{array}$ & $\begin{array}{c}2.11(2.02-2.19) \\
0.012 \\
\end{array}$ & $\begin{array}{c}1.55(1.39-1.89) \\
0.097\end{array}$ & $\begin{array}{c}2.12(1.97-2.23) \\
0.032 \\
\end{array}$ & $\begin{array}{c}0.66(0.51-0.81) \\
0.079 \\
\end{array}$ & $\begin{array}{c}5.33(5.18-5.69) \\
0.055 \\
\end{array}$ & $\begin{array}{c}3.13(3.02-3.49) \\
0.073\end{array}$ \\
\hline & RTW & $\begin{array}{c}3.53(3.28-3.71) \\
0.077\end{array}$ & $\begin{array}{c}0.93(0.71-1.24) \\
0.074\end{array}$ & $\begin{array}{c}1.11(0.90-1.34) \\
0.069\end{array}$ & $\begin{array}{c}1.16(1.09-1.52) \\
0.099\end{array}$ & $\begin{array}{c}2.56(2.39-2.77) \\
0.089\end{array}$ & $\begin{array}{c}0.78(0.56-0.91) \\
0.076\end{array}$ & $\begin{array}{c}6.68(6.49-6.84) \\
0.072\end{array}$ & $\begin{array}{c}2.56(2.37-2.82) \\
0.176\end{array}$ & $\begin{array}{c}0.57(0.28-0.80) \\
0.071\end{array}$ & $\begin{array}{c}2.69(2.35-2.87) \\
0.094\end{array}$ \\
\hline \multirow{2}{*}{ May } & SL & $\begin{array}{c}2.07(1.88-2.35) \\
0.068\end{array}$ & $\begin{array}{r}0.70(0.57-0.89) \\
0.063\end{array}$ & $\begin{array}{c}1.19(1.02-1.39) \\
0.074 \\
\end{array}$ & $\begin{array}{c}3.34(3.13-3.61) \\
0.215\end{array}$ & $\begin{array}{c}1.76(1.47-1.77) \\
0.010\end{array}$ & $\begin{array}{c}2.70(2.47-3.03) \\
0.086\end{array}$ & $\begin{array}{c}5.07(4.79-5.41) \\
0.077 \\
\end{array}$ & $\begin{array}{c}2.14(1.92-2.41) \\
0.115\end{array}$ & $\begin{array}{c}.12(1.97-2.23) \\
0.032\end{array}$ & $\begin{array}{c}0.76(0.58-0.88) \\
0.021\end{array}$ \\
\hline & RTW & $\begin{array}{c}2.12(1.97-2.23) \\
0.032\end{array}$ & $\begin{array}{c}1.27(1.13-1.39) \\
0.031\end{array}$ & $\begin{array}{c}0.79(0.54-1.89) \\
0.079\end{array}$ & $\begin{array}{c}4.33(4.06-4.69) \\
0.093\end{array}$ & $\begin{array}{c}0.75\left(\begin{array}{c}0.66-0.81) \\
0.031\end{array}\right) \\
0.031\end{array}$ & $\begin{array}{c}2.59(2.28-2.78) \\
0.068\end{array}$ & $\begin{array}{l}2.77(2.58-2.81) \\
0.052\end{array}$ & $\begin{array}{l}0.63(0.46-0.79) \\
0.062\end{array}$ & $\begin{array}{l}0.83(0.42-1.53) \\
0.213\end{array}$ & $\begin{array}{l}1.49(1.33-1.54) \\
0.012\end{array}$ \\
\hline \multirow{2}{*}{ June } & SL & $\begin{array}{c}3.58(3.23-3.65) \\
0.013\end{array}$ & $\begin{array}{l}0.63(0.37-0.88) \\
0.066\end{array}$ & $\begin{array}{c}0.90(0.67-1.10) \\
0.068\end{array}$ & $\begin{array}{l}0.81(0.69-0.92) \\
\mathbf{0 . 0 0 9}\end{array}$ & $\begin{array}{c}0.93(0.77-1.22) \\
0.076\end{array}$ & $\begin{array}{c}.53(2.36-2.79) \\
0.082\end{array}$ & $\begin{array}{c}1.98(1.67-2.28) \\
0.086\end{array}$ & $\begin{array}{c}2.37(2.08-2.58) \\
0.061\end{array}$ & $\begin{array}{c}2.61(2.37-2.84) \\
0.086\end{array}$ & $\begin{array}{c}4.38(4.19-4.64) \\
0.319\end{array}$ \\
\hline & RTW & $\begin{array}{c}3.56(3.39-3.72) \\
0.069\end{array}$ & $\begin{array}{c}1.50(1.34-1.77) \\
0.074\end{array}$ & $\begin{array}{l}2.79(2.58-2.95) \\
0.075\end{array}$ & $\begin{array}{l}1.19(0.89-1.40) \\
0.088\end{array}$ & $\begin{array}{c}0.47(0.29-0.60) \\
0.076\end{array}$ & $\begin{array}{c}1.27(1.08-1.45) \\
0.071\end{array}$ & $\begin{array}{l}0.94(0.79-1.24) \\
0.076\end{array}$ & $\begin{array}{l}1.07(0.88-1.24) \\
0.067\end{array}$ & $\begin{array}{l}0.89(0.61-1.07) \\
0.073\end{array}$ & $\begin{array}{c}3.08(2.88-3.35) \\
0.138\end{array}$ \\
\hline \multirow{2}{*}{ July } & SL & $\begin{array}{l}2.42(2-29-2.54) \\
0.014\end{array}$ & $\begin{array}{l}2.04(1.94-2.34) \\
0.065\end{array}$ & $\begin{array}{l}2.03(1.195-2.44) \\
0.072\end{array}$ & $\begin{array}{c}080(0.77-0.91) \\
0.010\end{array}$ & $\begin{array}{c}0.88(0.661-1.04) \\
0.114\end{array}$ & $\begin{array}{c}3.20(3.05-3.47) \\
0.077\end{array}$ & $\begin{array}{c}0.78(0.51-0.94) \\
0.114\end{array}$ & $\begin{array}{c}0.81(0.599 .0-94) \\
0.066\end{array}$ & $\begin{array}{c}.51(1.36-1.70) \\
0.074\end{array}$ & $\begin{array}{c}1.61(1.47-1.86) \\
0.024\end{array}$ \\
\hline & RTW & $\begin{array}{c}4.08(3.69-4.75) \\
0.212\end{array}$ & $\begin{array}{c}1.37(1.16-01.59) \\
0.080\end{array}$ & $\begin{array}{l}2.66(2.38-2.85) \\
0.074\end{array}$ & $\begin{array}{l}5.15(4.88-5.47) \\
0.084\end{array}$ & $\begin{array}{l}0.99(0.77-1.29) \\
0.073\end{array}$ & $\begin{array}{c}0.84(0.69-1.03) \\
0.076\end{array}$ & $\begin{array}{c}0.89(0.77-0.98) \\
0.063\end{array}$ & $\begin{array}{c}0.71(0.55-0.84) \\
0.074\end{array}$ & $\begin{array}{c}2.11(1.90-2.39) \\
0.065\end{array}$ & $\begin{array}{c}5.43(5.07-6.88) \\
0.166\end{array}$ \\
\hline \multirow{2}{*}{ August } & SL & $\begin{array}{c}1.72(1.48-1.49) \\
0.131\end{array}$ & $\begin{array}{c}0.72(0.49-0.84) \\
0.070 \\
\end{array}$ & $\begin{array}{c}2.29(2.03-2.49) \\
0.081\end{array}$ & $\begin{array}{c}0.81(0.70-0.92) \\
\mathbf{0 . 0 1 0}\end{array}$ & $\begin{array}{c}2.32(2.19-2.42) \\
0.020\end{array}$ & $\begin{array}{c}0.38(0.21-0.54) \\
0.084\end{array}$ & $\begin{array}{c}0.34(0.27-0.47) \\
0.012\end{array}$ & $\begin{array}{c}0.56(0.37-0.78) \\
0.083\end{array}$ & $\begin{array}{c}1.39(1.09-1.69) \\
0.077\end{array}$ & $\begin{array}{l}1.44(1.33-1.52) \\
0.040\end{array}$ \\
\hline & RTW & $\begin{array}{c}0.43(0.33-0.54) \\
0.012\end{array}$ & $\begin{array}{c}2.46(2.17-2.72) \\
0.071\end{array}$ & $\begin{array}{c}0.94(0.791-22) \\
0.076\end{array}$ & $\begin{array}{c}1.56(1.39-1.87) \\
0.179\end{array}$ & $\begin{array}{c}0.93(0.72-1.28) \\
0.086\end{array}$ & $\begin{array}{c}0.71(0.47-0.94) \\
0.083\end{array}$ & $\begin{array}{c}.16(2.89-3.42) \\
0.189\end{array}$ & $\begin{array}{c}2.08(1.90-2.39) \\
0.059\end{array}$ & $\begin{array}{c}0.70(0.46-0.84) \\
0.070\end{array}$ & $\begin{array}{c}.68(3.06-3.84) \\
0.119\end{array}$ \\
\hline \multirow{2}{*}{ September } & SL & $\begin{array}{c}2.28(2.12-2.39) \\
0.022\end{array}$ & $\begin{array}{c}2.09(1.82-2.31) \\
0.085\end{array}$ & $\begin{array}{c}0.98(0.71-1.34) \\
0.114\end{array}$ & $\begin{array}{c}085(0.69-0.93) \\
0.021\end{array}$ & $\begin{array}{c}2.52(2.33-2.64) \\
0.010\end{array}$ & $\begin{array}{c}1.61(1.47-1.88) \\
0.077\end{array}$ & $\begin{array}{c}5.34(5.18-5.81) \\
0.315\end{array}$ & $\begin{array}{c}2.63(2.47-2.88) \\
0.093\end{array}$ & $\begin{array}{c}2.90(2.67-3.12) \\
0.066\end{array}$ & $\begin{array}{c}3.47(3.18-3.75) \\
0.081\end{array}$ \\
\hline & RTW & $\begin{array}{c}.76(3.59-3.92) \\
0.089\end{array}$ & $\begin{array}{c}0.43(0.22-0.69) \\
0.088\end{array}$ & $\begin{array}{c}0.69(0.47-0.89) \\
0.083\end{array}$ & $\begin{array}{c}1.68(1.41-1.84) \\
0.112\end{array}$ & $\begin{array}{c}0.78(0.59-0.94) \\
0.072\end{array}$ & $\begin{array}{c}5.38(5.19-5.55) \\
0.150\end{array}$ & $\begin{array}{c}.33(1.07-1.69) \\
0.093\end{array}$ & $\begin{array}{c}1.50(1.29-1.82) \\
0.289\end{array}$ & $\begin{array}{c}2.29(2.08-2.58) \\
0.065\end{array}$ & $\begin{array}{c}6.56(6.19-9.82) \\
0.099\end{array}$ \\
\hline \multirow{2}{*}{ October } & SL & $\begin{array}{c}3.16(3.02-3.44) \\
0.010\end{array}$ & $\begin{array}{c}2.47(2.28-2.69) \\
0.061\end{array}$ & $\begin{array}{l}0.73(0.57-1.02) \\
0.313\end{array}$ & $\begin{array}{c}1.17(0.88-1.35) \\
0.091\end{array}$ & $\begin{array}{c}2.09(1.85-2.35) \\
0.131\end{array}$ & $\begin{array}{c}0.93(0.77-1.29) \\
0.210\end{array}$ & $\begin{array}{c}4.37(4.08-4.75) \\
0.091\end{array}$ & $\begin{array}{c}2.14(1.88-2.46) \\
0.106\end{array}$ & $\begin{array}{c}2.33(2.16-2.54) \\
0.062\end{array}$ & $\begin{array}{c}5.44(4.28-5.91) \\
0.095\end{array}$ \\
\hline & RTW & $\begin{array}{l}0.36(0.22-0.47) \\
0.023\end{array}$ & $\begin{array}{l}1.37(1.01-1.56) \\
0.083\end{array}$ & $\begin{array}{c}2.29(2.07-2.48) \\
0.079\end{array}$ & $1.19(1.08-1.28)$ & $\begin{array}{c}0.33(0.26-0.44) \\
0.017\end{array}$ & $\begin{array}{c}3.56(3.39-3.72) \\
0.079\end{array}$ & $\begin{array}{l}3.12(2.87-3.43) \\
0.032\end{array}$ & $\begin{array}{c}3.23(3.05-3.59) \\
0.075\end{array}$ & $\begin{array}{l}2.27(2.08-2.75) \\
0.171\end{array}$ & $\begin{array}{l}3.93(3.08-4.19) \\
0.093\end{array}$ \\
\hline \multirow{2}{*}{ November } & SL & $\begin{array}{l}2.18(1.97-2.32) \\
0.042\end{array}$ & $0.89(0.59-1.04)$ & $\begin{array}{c}2.94(2.68-3.12) \\
0.119\end{array}$ & $\begin{array}{l}3.58(3.39-3.70) \\
0.62\end{array}$ & $\begin{array}{c}0.83(0.67-1.08) \\
0.74\end{array}$ & $\begin{array}{c}4.44(4.28-4.81) \\
0.215\end{array}$ & $\begin{array}{l}1.81(1.49-1.97) \\
0.063\end{array}$ & $\begin{array}{c}2.57(2.39-2.82) \\
0.081\end{array}$ & $\begin{array}{l}2.20(2.08-2.45) \\
0.087\end{array}$ & $\begin{array}{l}3.57(3.29-3.85) \\
0.071\end{array}$ \\
\hline & RTW & $\begin{array}{c}1.16(0.88-1.41) \\
0.079\end{array}$ & $\begin{array}{c}4.07(3.77-3.35) \\
0.091\end{array}$ & $\begin{array}{c}1.53(1.26-1.79) \\
0.067\end{array}$ & $\begin{array}{c}4.07(3.88-3.41) \\
0.201\end{array}$ & $\begin{array}{c}065(0.55-0.78) \\
0.041\end{array}$ & $\begin{array}{c}2.03(1.78-2.49) \\
0.184\end{array}$ & $\begin{array}{c}3.93(3.47-4.88) \\
0.266\end{array}$ & $\begin{array}{c}0.66(0.47-0.88) \\
0.066\end{array}$ & $\begin{array}{c}0.85(0.37-0.88) \\
0.066\end{array}$ & $\begin{array}{c}2.12(1.97-2.23) \\
0.032\end{array}$ \\
\hline \multirow{2}{*}{ December } & SL & & & & & & & & & & \\
\hline & RTW & $\begin{array}{c}0.40(0.29-0.58) \\
0.035\end{array}$ & $\begin{array}{c}.06(4.37-5.54) \\
0.077\end{array}$ & $\begin{array}{c}0.51(0.34-0.71) \\
0.065\end{array}$ & $\begin{array}{l}1.14(0.91-1.41) \\
0.196\end{array}$ & $\begin{array}{c}6.21(5.35-6.90) \\
0.323\end{array}$ & $\begin{array}{l}0.72(0.54-0.88) \\
0.061\end{array}$ & $\begin{array}{l}4.32(3.86-4.75) \\
0.084\end{array}$ & $\begin{array}{c}0.91(0.77-1.22) \\
0.066\end{array}$ & $\begin{array}{c}2.86(2.67-3.29) \\
0.062\end{array}$ & $\begin{array}{c}2.99(2.62-3.42) \\
0.081\end{array}$ \\
\hline
\end{tabular}

Cox regression model of duration of the SL, in days.

\begin{tabular}{|c|c|c|c|c|c|c|c|c|c|}
\hline Duration of SL & & & & & & & & & \\
\hline HR & 0.523 & 0.635 & 0,489 & 0,517 & 0,625 & 0,447 & 1,046 & 1,169 & 0,559 \\
\hline IC & $0.456-0.599$ & $0,611-0,659$ & $0,0299-0,798$ & $0,477-0,569$ & $0,0,599-0,734$ & $0,380-0,525$ & $0,470-2,329$ & $1,062-1,287$ & $0,536-0,0,8$ \\
\hline$P$ value & $<0.001$ & $<0.001$ & 0.004 & $<0.001$ & $<0.001$ & $<0.001$ & 0.912 & $<0.001$ & $<0.001$ \\
\hline
\end{tabular}

SL: Sick leave; RTW: Return to work. Bold type: High statistical significance (P value less than 0.01). Italic type: $\mathrm{P}$ value $<0.05$. Reference categories: Year to begin SL: 2009 (schizophrenic disorders, delusional disorders and other nonorganic psychoses, alcohol dependence syndrome , drug dependence and nondependent abuse of drugs , symptoms or syndromes not elsewhere classified and physiological malfunction arising from mental factors, depressive disorder not elsewhere classified); 2010 (acute reaction to stress); 2017 (episodic mood disorders); 2019 (anxiety, dissociative and somatoform disorders and personality disorders and disturbance of conduct not elsewhere classified). Month of SL: December (for all Models). Month of RTW: January (for all Models). Duration of SL: Anxiety, dissociative and somatoform disorders

Table 5. Multivariate logistic regression model of economic variables.

\begin{tabular}{|c|c|c|c|c|c|c|c|c|c|c|}
\hline & $\begin{array}{c}\text { Schizophrenic } \\
\text { disorders }\end{array}$ & Episodic mood disorders & $\begin{array}{l}\text { Delusional disorders } \\
\text { and other nonorganic } \\
\text { psychoses }\end{array}$ & $\begin{array}{l}\text { Anxiety, } \\
\text { dissociative and } \\
\text { somatoform } \\
\text { disorders }\end{array}$ & $\begin{array}{l}\text { Personality } \\
\text { disorders and } \\
\text { disturbance of } \\
\text { conduct not } \\
\text { elsewhere } \\
\text { classified }\end{array}$ & $\begin{array}{c}\text { Alcohol } \\
\text { dependence } \\
\text { syndrome }\end{array}$ & $\begin{array}{l}\text { Drug dependence and } \\
\text { nondependent abuse of } \\
\text { drugs }\end{array}$ & $\begin{array}{l}\text { Special symptoms or } \\
\text { syndromes not } \\
\text { elsewwerer classififed } \\
\text { and physiological } \\
\text { malfunction arising } \\
\text { from mental factors }\end{array}$ & $\begin{array}{l}\text { Acute reaction to } \\
\text { stress }\end{array}$ & $\begin{array}{l}\text { Depressive disorder not } \\
\text { elsewhere classified }\end{array}$ \\
\hline Type of contract & $\begin{array}{c}\mathrm{OR} \text { (C195\%) } \\
\text { p value }\end{array}$ & $\begin{array}{c}\mathrm{OR} \text { (C195\%) } \\
\text { p value }\end{array}$ & $\begin{array}{c}\mathrm{OR} \text { (Cl 195\%) } \\
\text { p value }\end{array}$ & $\begin{array}{c}\mathrm{OR} \text { (Cl 195\%) } \\
\text { p value }\end{array}$ & $\begin{array}{c}\mathrm{OR} \text { (Cl } 195 \%) \\
\text { p value }\end{array}$ & $\begin{array}{c}\mathrm{OR} \text { (CI } 95 \%) \\
\text { p value }\end{array}$ & $\begin{array}{c}\mathrm{OR} \text { (Cl } 95 \%) \\
\text { p value }\end{array}$ & $\begin{array}{c}\text { OR (Cl 195\%) } \\
\text { p value }\end{array}$ & $\begin{array}{c}\mathrm{OR} \text { (Cl } 95 \%) \\
\mathrm{p} \text { value }\end{array}$ & $\begin{array}{c}\mathrm{OR} \text { (CI 195\%) } \\
\text { p value }\end{array}$ \\
\hline Direct payment & $\begin{array}{c}1.61(1.43-1.89) \\
0.079\end{array}$ & $\begin{array}{l}1.21(1.13-1.128) \\
\mathbf{0 . 0 1 0}\end{array}$ & $\begin{array}{c}1.44(1.39-1.52) \\
0.021\end{array}$ & $\begin{array}{c}0.89(0.72-0.97) \\
0.009\end{array}$ & $2.11\left(\begin{array}{c}(1.98-2.28) \\
0.021\end{array}\right.$ & $\begin{array}{l}1.66(1.51-1.89) \\
0.071\end{array}$ & $\begin{array}{c}2.33(2.22-2.39) \\
0.012\end{array}$ & $\begin{array}{l}0.29(0.20-0.37) \\
0.022\end{array}$ & $\begin{array}{c}0.53(0.47-0.59) \\
0.013\end{array}$ & $\begin{array}{l}2.54(2.46-2.61) \\
0.024\end{array}$ \\
\hline $\begin{array}{c}\text { Contract termination } \\
\text { during SL }\end{array}$ & $\begin{array}{c}4.27(3.08-4.91) \\
0.211\end{array}$ & $\begin{array}{c}095(0.75-1.38) \\
0.061\end{array}$ & $\begin{array}{c}2.01(1.88-2.49) \\
0.84\end{array}$ & $\begin{array}{c}3.90(3.67-4.28) \\
0.066\end{array}$ & $\begin{array}{c}0.58(0.50-0.022) \\
0.011\end{array}$ & $\begin{array}{l}0.87(0.68-1.31) \\
0.221\end{array}$ & $\begin{array}{c}060(0.49-0.79) \\
0.067\end{array}$ & $\begin{array}{c}2.33(2.07-2.99) \\
0.124\end{array}$ & $\begin{array}{c}0.93(0.77-1.48) \\
0.166\end{array}$ & $\begin{array}{c}0.80(0.72-0.88) \\
0.044\end{array}$ \\
\hline \multicolumn{11}{|l|}{$\begin{array}{c}\text { Type of social } \\
\text { security } \\
\text { contributions }\end{array}$} \\
\hline Self employed & $\begin{array}{c}4.56(3.19-4.92) \\
0.189\end{array}$ & $\begin{array}{c}3.92(3.37-4.63) \\
0.092 \\
\end{array}$ & $\begin{array}{c}5.23(4.05-6.69) \\
0.095\end{array}$ & $\begin{array}{c}9.79(7.78-10.38) \\
0.023\end{array}$ & $\begin{array}{c}4.11(3.20-5.39) \\
0.265\end{array}$ & $\begin{array}{c}5.43(4.07-6.88) \\
0.196\end{array}$ & $\begin{array}{c}31.63(25.96-37.80) \\
0.009\end{array}$ & $\begin{array}{c}42.03(35.23-48.23) \\
0.010\end{array}$ & $\begin{array}{c}3.93(3.08-4.53) \\
0.293 \\
\end{array}$ & $\begin{array}{c}12.78(10.56-13.96) \\
\mathbf{0 . 0 1 0}\end{array}$ \\
\hline General scheme & $\begin{array}{c}8.66(8.08-9.45) \\
0.087\end{array}$ & $\begin{array}{c}15.15(14.78-17.97) \\
0.058\end{array}$ & $\begin{array}{c}10.89(8.07-12.29) \\
0.093\end{array}$ & $\begin{array}{c}0.84(0.69 .1-03) \\
0.070\end{array}$ & $\begin{array}{c}9.89(8.77-11.98) \\
0.183\end{array}$ & $\begin{array}{c}0.71(0.59-0.88) \\
0.078 \\
\end{array}$ & $\begin{array}{c}\begin{array}{c}61.40(52.34-68.99) \\
0.014\end{array} \\
\end{array}$ & $\begin{array}{c}37.23(31.23 .42 .34) \\
0.014\end{array}$ & $\begin{array}{c}12.03(9.78-15.49) \\
0.089\end{array}$ & $\begin{array}{c}.03(6.78-12.49) \\
0.184\end{array}$ \\
\hline
\end{tabular}




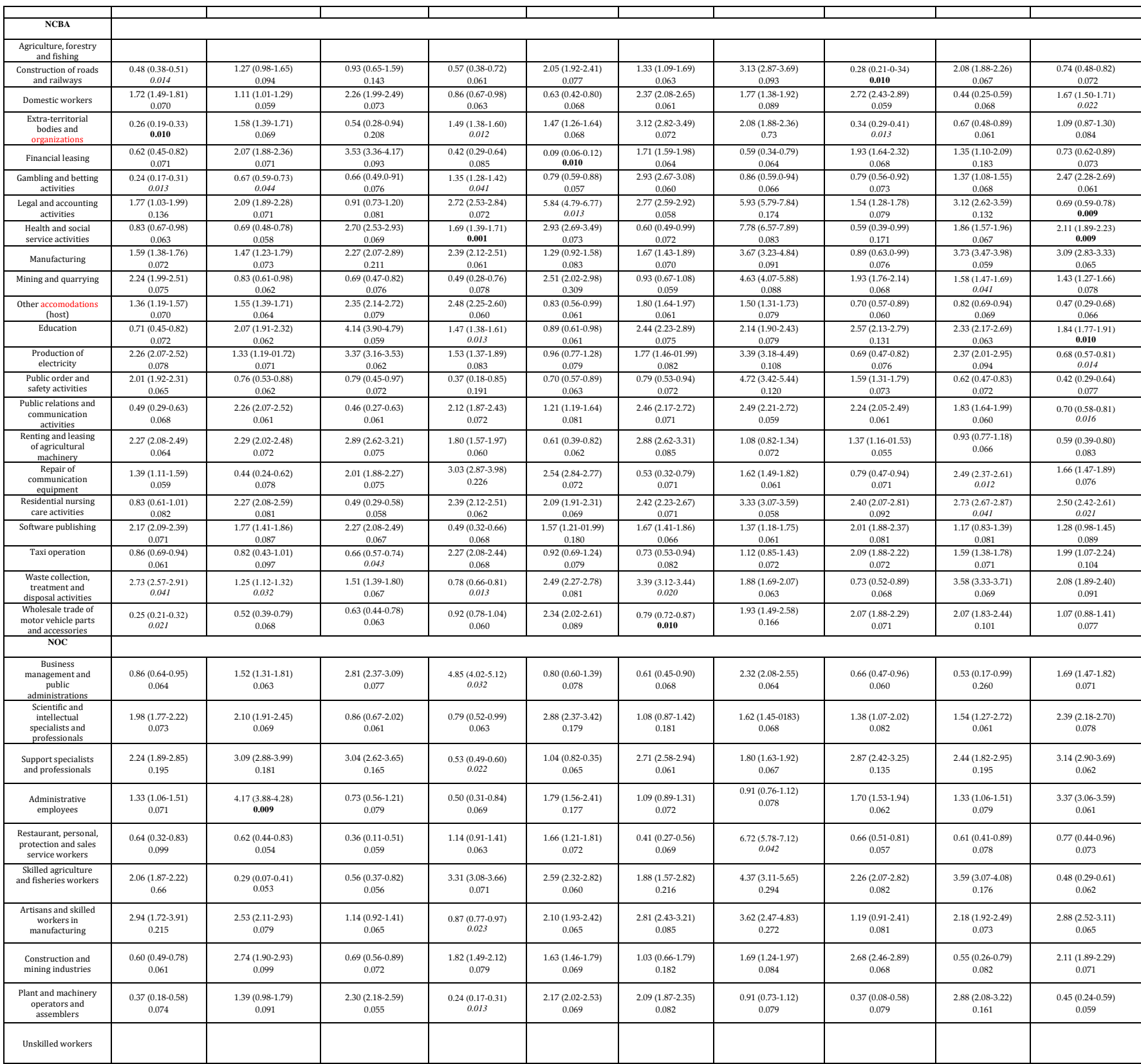

NOC: National Occupation Code, 1994; NCBA: National Code of Business Activity, 2009. Bold type: High statistical significance (P value less than 0.01). Italic type: $\mathrm{P}$ value $<0.05$

Reference categories: Type of contract: Delegate Payment (for all Models). Type of social security contributions: Others (for all Models). NCBA: Agriculture, forestry and fishing (for all Models). NOC: Unskilled workers (for all Models)

during or after the period of sick leave of non-work origin (there are greater possibilities of finding a new job).

Without distinguishing between age or sex, the most common causes of SL due to common illness in Spain are psychiatric pathologies, osteo-muscular pathologies and oncological pathologies (27). Mental disorders had an economic cost of 7,019 million Euros, of which direct medical costs accounted for 36.9\% (2,777 million Euros), costs associated with informal care 17.7\% (with 1,245 million euros) and costs for sick leave 42.7\% (2,997 million Euros) (see Table 1). Taken together, the total costs represented about 1\% of the country's Gross Domestic Product (GDP) (28). The mutual insurance companies have been managing SL for common (non-occupational) illnesses for more than 20 years, and in that time resources have been put in place which rationally monitor the medical justification for these periods of disability. This daily management operates in 
conjunction with other non-medical justifications for prolonging SL: social, social-family, work, economic reasons, etc.

These data are alarming due to the significant expense that this employment situation entails for companies, mutual insurance companies, the State and the workers themselves, which, while being perfectly justified, does not exempt them from succumbing to the rentier absenteeism condemned on numerous occasions, and evidenced by the existence of Medical Evaluation Tribunals. According to employers- federations, the existence of this absenteeism is directly related to the improvement of the economy, for two reasons: the less acute the economic crisis, the more workers are hired, (statistical data), and their fear of losing their job during or after the period of non-work-related SL declines (there are more opportunities to find a new job).

The existence of high levels of sick leave and the absenteeism and rentier absenteeism associated with it is now an accepted fact, and recruitment companies, mutual insurance companies, social stakeholders and sometimes workers themselves have proposed various solutions, including preventive healthcare measures, the identification of risk factors, interventions in primary healthcare, rationalizing working hours, and initiatives for flexible working hours to facilitate a balance between work and personal life, as well as increasing workers' motivation.

This descriptive and analytical study has used the database of a regional mutual insurance company over a period long enough to obtain a critical mass of information that provides the most conclusive results possible in the area of predictive factors of SL due to mental illness. A period of a decade has been included to cover the global financial and economic crisis of 20092012 and to obtain information on all of the mental illnesses in the database that cause SL.

Three groups of variables (predictors) were selected in the methodological design, and some of them were created in order to receive more robust statistical treatment. As a result, the worker's municipality of residence was grouped in the Catalan regions by GDP per inhabitant and by population density, and the worker's age was grouped into 6 cohorts. The dependent variable was grouped into 10 groups of mental illnesses according to the ICD-9 (Spanish), based on the principal specific diagnosis in the medical history. The NOC was not coded for all the years covered by the study, and its calculation covers workers on SL due to common non-occupational illnesses from 2012 onwards.

\section{$\underline{\text { Statistical descriptive results }}$}

The statistical results include several findings related to the variables analyzed. Affective disorders account for more than $75 \%$ of all mental disorders, with neurotic disorders (anxiety, depression) being the most common. These mental pathologies are the most extensively analyzed in epidemiological studies related to SL due to mental disorders (13). Moreover, these diagnostic groups are those which the medical tribunals rule are fit to return to work after a psychiatric examination (29).

The bulk of patients on SL due to mental illness are located in the cohorts aged 30 to 50 years old, which is consistent with the results of other studies (30). Proportional to population density, the most densely inhabited Catalan regions (metropolitan areas) have a higher incidence of SL due to mental illness. Similar results have been known for a long time (31). As regards the relationship of seasonality with the incidence of SL due to mental illnesses, some mental illnesses are known to be related to certain seasons of the year, and a higher seasonal incidence of mental illness could be related to a higher incidence of SL (32). In our study, the months with the lowest levels of onset of SL cases are during the periods prior to the summer holidays and at the end of the year, and the months with the lowest levels of SL due to mental illness are August and December; These 
results are partly consistent studies already published, although they do not belong to a similar geographic area (33) and should be reinforced with further studies.

The reason for returning to work is mostly $(83 \%)$ cure or improvement permitting work, while $7 \%$ of workers were forced to return to work by the Medical Inspector. These workers are a part of the rentier group during the period studied. Preventive actions must be taken against these absenteeist workers to minimize the negative socio-economic consequences.

The distribution by year of the SL events shows results comparable to a previous study (20) in which during the years of the economic crisis, the number of SL events due to common nonwork-related illnesses fell in comparison with the pre- and post-financial and economic crisis period. Similar results were found for the other mutual insurance companies in terms of the proportion of the types of payment during the SL and the type of contract of workers with mental illness: delegated payment predominates over direct payment, and workers employed in the general system over self-employed workers (20).

Predictive variables of SL due to mental illness according to the results of regression models

The results from the regression models provide information about mental illnesses on predictive factors for the appearance of SL due to mental disorders. The model associates affective pathologies with metropolitan areas, while the same pathologies are associated in a different way if their per capita income is taken into account. Consequently, wealthy workers and those in large cities are risk factors for anxiety disorders, while depressive disorders are associated with poor workers and those in large cities. This sociodemographic distribution is partially described in the literature (34) and should be covered by other studies. Meanwhile, the probability of appearance of mental illnesses according to gender follows a predefined pattern in the literature (35), and in general terms being a woman is a risk factor for SL due to anxiety, depression and personality disorders, while being a man is a risk factor for drug dependence and non-dependence abuse of drugs.

The results of the distribution by month as an employment-related predictor may have a double explanation. First, there is psychiatric meteoropathology and biometeorology of psychological phenomena $(36,37)$ and second, rentier absenteeism $(38)$. Further studies will be necessary to corroborate these results. In the first months of the SL period, anxiety disorders decline in June, July, August, and September, which are the most common vacation periods (possibly due to rentier absenteeism), while the probability of SL due to depression increases during the summer months (June, July, and August) (a possible biometeorological factor). Together with other risk factors, this seasonal distribution of neurotic disorders is considered a determinant factor in the prevalence of these pathologies $(39,40)$. The association between starting SL due to personality and schizophrenic disorders and the summer months could be related to seasonality and personality $(41,42)$. As for the month of returning to work, our results provide a distribution that is relevant in some cases: the number of patients on SL due to depression significantly declines in May (which is related to the months with the highest probability of SL: possible rentier absenteeism), and the probability of returning to work declines significantly among patients with psychotic pathologies in the spring and summer months (a possible biometeorological factor).

Although in our study the total workers on SL due to mental illness fell during the most recent economic crisis (2009-2015), anxiety and depression disorders and episodic mood disorders significantly increased. These results are consistent coincide with similar studies in other countries (43) 
As for the type of payment predictor (that the worker receives during the period of SL due to mental illness), workers with direct payment have a higher probability of SL due to psychotic diseases, and a lower probability of SL due to neurotic diseases. These results could be explained by the fact that anxiety and depression disorders are less common among these workers because they are subject to less psychosocial risk at work (44). This predictor also indicates that when the worker has been diagnosed with a depressive or personality disorder, the probability that the company will not terminate the contract increases. Among affective disorders, depression is known to be the cause of less rentier absenteeism than anxiety disorders (45), and this could act as a curb on the company dismissing the worker during the period of SL. Furthermore, depressive disorder is the diagnosis that is most commonly associated with continuation of the SL period.

Cox regression analysis indicates that almost all mental illness groups tend to have a shorter duration of SL compared to adaptive disorders with an anxious component, where rentier absenteeism is more significant, and more patients in this group are referred to medical inspectors to be ordered to return to work early (46). These results show that these workers require important preventive work to shorten the duration of their SL. The average age of patients on SL due to mental illness ranges between an average of 30 and 45 years old for each diagnostic group, which is the normal distribution for these diseases during working ages $(47,48)$.

In this study, some professions and business activities have been observed to constitute predictive risk factors for SL due to anxiety and depression disorders, personality disorders, schizophrenic disorders and alcohol dependence. Employees in welfare service occupations in the healthcare, education and social services sectors work in professions that have a high risk of SL for mental disorders (49), although this study was conducted in a different geographic area. Meanwhile, there are several possible etiopathogenic mechanisms involved between suffering from a mental disorder and its relationship with work (50). Exposure to occupational stress related to the lack of an opportunity to use one's abilities leads to fatigue and various mental disorders, such as adaptive disorders (51). On the other hand, exposure to psychosocial risks at work may contribute to triggering a mental disorder to which the worker is vulnerable, and the psychosocial risk of work acts as a triggering or aggravating factor (52). Further studies should add more scientific evidence to these findings.

This study has three limitations that may be resolved in future studies. The first is the availability of the population insured by the mutual insurance company by region and year, in order to obtain the real proportion in the distribution of SL due to mental illness with these predictors. Despite this limitation, the results are very similar to those expected, without taking the insured base population into account. The second is that the study could be completed with more variables that could not be obtained from the database used for this retrospective study, such as the level of education, social class, and established psychiatric risk factors. To that end, prospective studies should be carried out which select and identify other variables that represent risk factors for SL due to mental illness. The third is related to the geographical area studied (an industrialized region of southern Europe), since the results may not be extrapolated to other regions that are different in socio-demographic-economic terms. The results of this work should therefore be compared with future studies from similar regions and over similar periods of time.

All mental illnesses susceptible to onset at working age have been analyzed in groups according to the ICD-9, in order to improve knowledge in this field as a whole, and not only of the mental illnesses with the highest prevalence. The value of this work is also determined by (i) the long study period, which provided a significant amount of data to achieve robust results, as well as the evolution of SL due to mental illness over time; (ii) our demonstration that for the development of mental illnesses in the demographic, socio-economic and occupational areas could be predictors for workers taking periods of SL of variable duration due to these pathologies; 
(iii) analyzing risk factors of seasonality, geographic distribution and economic level has provided information on the behavior of SL due to mental illness in a Mediterranean region with different characteristics from other parts of Europe for which studies in this field have been produced. Further studies, mainly of a prospective nature, should corroborate these results. These studies should include all psychiatric pathologies during working age, and cover different regions with various socio-economic, labor and demographic factors. A wide selection of common risk factors would make it possible to verify and reinforce the accumulated scientific evidence, or to generate fresh evidence. An effective preventive action with the identified risk factors would improve the region's socio-economic environment.

Businesses and mutual insurance companies should implement plans to reduce absenteeism. These plans should include several strategies: making the company an exciting place, implementing a healthy life plan, promoting and facilitating assistance by mental health specialists, facilitating telework, fostering a work-life balance, establishing regular team meetings, promoting work based on objectives, rewarding presence at work and creating participatory events. Protocols for the prevention of sick leave due to mental illness should be implemented, and three prevention systems established: primary (aimed at reducing the incidence of health problems through knowledge and the elimination of causal factors in people or groups at risk, through health education programs to improve the quality of work life and cope with health risk factors), secondary (aimed at early diagnosis and more effective treatment to reduce the duration of the disorder and the risk of complications); and tertiary (intervening to address the mental health problem and reduce the risk of relapses and subsequent complications).

\section{Conclusions}

In conclusion:

1. Risk factors for the development of mental illnesses in demographic, socioeconomic and occupational areas could be predictors for workers to take periods of SL of variable duration due to these pathologies. The cohorts aged 30 to 50 years old and women are the most affected.

2. Diagnostic groups related to neurotic disorders are the most common cause of SL due to mental illness, with the most populated and most rich regions of Catalonia most affected. This group of psychiatric pathologies also accounts for the most cases of rentier absenteeism, and the average SL period is shorter than for psychotic disorders.

3. Seasonality is observed at the beginning and end of SL due to mental illness, and the fewest new episodes of SL are recorded in the months prior to the normal vacation periods, and August and December have the fewest cases of returning to work after mental illness. These cases may be due to a combination of rentier absenteeism and psychiatric meteoropathology. SL due to mental illness is less common in periods of economic crisis.

4. Self-employed workers are more likely to begin a period of SL due to mental illness than workers employed in the general system. When the worker has been diagnosed with a depressive or personality disorder, the probability that the company will not terminate the contract increases. Companies with education activities at any level, companies in the health and sociohealth fields, and manufacturing companies have more workers on SL due to mental illness.

5. Population density and gross domestic product per capita, the gender and age cohort, the season of the year, the type of payment, the type of contract, and the worker's business and profession could predict SL due to mental illness. Mutual insurance companies should plan interventions to minimize some of these factors in order to avoid important socioeconomic 
consequences. These interventions should be preventive at three levels of action, according to the evolution of the workers' mental health.

\section{Author Contributions:}

FFG: Study conception and design, acquisition of data, analysis and interpretation of data, drafting of manuscript and critical revision of manuscript.

CM: Analysis and interpretation of data and critical revision of manuscript.

AA: Analysis and interpretation of data and critical revision of manuscript.

LFB: Study conception and design, acquisition of data, analysis and interpretation of data and drafting of manuscript.

All authors have read and approved the final manuscript.

Funding: Not applicable

Acknowledgments: Not applicable

Conflicts of Interest: The authors declare no conflict of interest.

Institutional Review Board Statement: Ethical review and approval were waived for this study, due to the investigation only involves data of patients without personal identification in the database analyzed.

Informed Consent Statement: Not applicable

Datasets are deposited in a publicly available database: 3rd Party Data Restrictions apply to the availability of these data. Data was obtained from EGARSAT and are available from the authors with the permission of EGARSAT.

\section{References}

1. Delclos J, Garcia S, López JC. Duración de la incapacidad temporal por contingencia común por grupos diagnósticos. Arch Prev Riesgos Labor, 2010; 13:180-7.

2. Benavides FG, Plana M, Serra C. Reincorporación al trabajo después de un episodio de incapacidad temporal por contingencia común: papel de la edad, el sexo, la actividad económica y la comunidad autónoma. Rev Esp Salud Publica, 2007; 81:183-90.

3. Roelen CAM, Koopmans PC, Hoedeman R. Trends in the incidence of sickness absence due to common mental disorders between 2001 and 2007 in the Netherlands. Eur J Public Health, 2009; 19:625-30.

4. Romera I, Perez V, Menchon JM, Delgado-Cohen H, Polavieja P, Gilaberte I. Social and occupational functioning impairment in patients in partial versus complete remission of a major depressive disorder episode. A six-month prospective epidemiological study. Eur Psychiatry 2010; 25: 58-65.

5. Vaez M, Rylander G, Nygren A, Asberg M, Alexanderson K. Sickness absence and disability pension in a cohort of employees initially on long-term sickness absence due to psychiatric disorders in Sweden. Soc Psychiatry Psychiatr Epidemiol 2007; 42: 381-388.

6. Ballesteros Polo M, Serra Pujadas C, Miguel Martinez J. Comparación del coste de la incapacidad temporal por contingencia común en 2006 entre las provincias de Barcelona y Madrid. Rev Esp de Salud Publica, 2009; 83:453-61.

7. OECD (2011) The OECD Mental Health and Work Project. Sick on the job? Myths and Realities about Mental Health and Work (http://www.oecd.org/els/emp/sickonthejob2011.htm). Accessed May 2020.

8. Plaisier I, Beekman AT, de Graaf R. Work functioning in persons with depressive and anxiety disorders: the role of specific psychopathological characteristics. J Affect Disord, 2010; 125:198-206. 
9. Stein DJ, Szatmari P, Gaebel W, Berk M, Vieta E, Maj M, Anna de Vries Y, Roest AM, de Jonge P, Maercker A, Brewin CR, Pike KM, Grilo CM , Fineberg NA, Briken P, Cohen-Kettenis PT, Reed GM. Mental, behavioral and neurodevelopmental disorders in the ICD-11: an international perspective on key changes and controversies. BMC Med. 2020; 18: 21.

10. Palmer VJ, Chondros P, Piper D, Callander R, Weavell W, Godbee K, Potiriadis M, Richard L, Densely K, Herrman H, Furler J, Pierce D, Schuster T, Iedema R, Gunn J. The CORE study protocol: a stepped wedge cluster randomised controlled trial to test a co-design technique to optimise psychosocial recovery outcomes for people affected by mental illness in the community mental health setting. BMJ Open. 2015; 5(3): e006688.

11. Scott KM, Obaid Al-Hamzawi A, Andrade LH, Borges G, Caldas-de-Almeida JM, Fiestas F, Gureje O, Hu C, Karam EG, Kawakami N, Lee S, Levinson D, Lim CCW, Navarro-Mateu F, Okoliyski M, Posada-Villa J, Torres Y, Williams DR, Zakhozha V, Kessler RC. Associations between subjective social status and DSMIV mental disorders: Results from the World Mental Health Survey. JAMA Psychiatry 2019; 71(12): 14001408.

12. Furber G, Segal L, Leach M, Turnbull C, Procter N, Diamond M, Miller S, McGorry P. Preventing mental illness: closing the evidence-practice gap through workforce and services planning. BMC Health Serv Res. 2015; 15: 283.

13. Lund C, Brooke-Sumner C, Baingana F, Baron EC, Breuer E, Chandra P, Haushofer J, Herrman, Jordans M, Kieling C, Medina-Mora ME, Morgan E, Omigbodun O, Tol W, Patel V, Saxena S. Social determinants of mental disorders and the Sustainable Development Goals: a systematic review of reviews. The Lancet Psychiatry, 2018; 5(4): 357-36914.

14. Cornelius LR, van der Klink JJL, Groothoff JW, Brouwer S. Prognostic factors of long term disability due to mental disorders: a systematic review. J Occup Rehabil, 2011; 21:259-274.

15. Catalina-Romero C, Martinez-Munoz P, Quevedo-Aguado L, Ruiz-Moraga M, Fernandez-Labandera C, Calvo-Bonacho E. Predictors of the duration of non-work-related sickness absence due to anxiety disorders. Gac Sanit 2013; 27: 40-46.

16. Sandanger I, Nygard JF, Brage S, Tellnes G. Relation between health problems and sickness absence: gender and age differences - a comparison of low-back pain, psychiatric disorders, and injuries. Scand J Public Health 2000; 28: 244-252.

17. Royo-Bordonada MA. La duración de la incapacidad laboral y sus factores asociados. Gac Sanit 1999; 13: 177-184.

18. Mittendorfer-Rutz E, Härkänen T, Tiihonen J, Haukka J. Association of Socio-Demographic Factors, SickLeave and Health Care Patterns with the Risk of Being Granted a Disability Pension among Psychiatric Outpatients with Depression. PLoS One. 2014; 9(6): e99869

19. Kokkinen L, Kouvonen A, Buscariolli, Koskinen A, Varje P, Väänänen A. Human service work and longterm sickness absence due to mental disorders: a prospective study of gender-specific patterns in 1,466,100 employees. Annals of Epidemiol, 2019; 31 (3): 57-61.

20. Real E, Jover L, Verdaguer R, Griera A, Segalàs C, Alonso P, Contreras F, Arteman A, Menchón, JM. Factors Associated with Long-Term Sickness Absence Due to Mental Disorders: A Cohort Study of 7.112 Patients during the Spanish Economic Crisis. PLoS One. 2016; 11(1): e0146382.

21. Dorner TE, Mittendorfer-Rutz E. Socioeconomic inequalities in treatment of individuals with common mental disorders regarding subsequent development of mental illness. Soc Psychiatry Psychiatr Epidemiol. 2017; 52(8): 1015-1022. 
22. Torvik FA, Ystrom E, Czajkowski N, Tambs K, Røysamb E, Ørstavik R, Knudsen GP, Kendler ks, Reichborn-Kjennerud T. Socioeconomic status and sickness absence granted for mental and somatic disorders: a prospective study of young adult twins. BMC Public Health volume 15, Article number: 134 (2015).

23. Roelen CAM, van Rhenen W, Koopmans PC, Bültmann U, Groothoff JW, van der Klink JJL. Sickness absence due to mental health disorders - a societal perspective. Occup Med 2012;62:379-381.

24. Dewa CS, Loong D, Bonato S, Hees H. Incidence rates of sickness absence related to mental disorders: a systematic literature review. BMC Public Health. 2014; 14: 205.

25.INEDatabase1994https://www.ine.es/dyngs/INEbase/en/operacion.htm?c=Estadistica_C\&cid=125473617 7033\&menu=ultiDatos\&idp=1254735976614. Accessed 29 October 2020

26.INEDatabase.2009https://www.ine.es/dyngs/INEbase/en/operacion.htm?c=Estadistica_C\&cid=12547361 77032\&menu=ultiDatos\&idp=1254735976614. Accessed 29 October 2020.

27. Randstad Database. 2019. https://www.research.randstad.es/wp-content/uploads/2019/09/RANDSTADRESEARCH-Informe-de-Absentismo-laboral-SEPTIEMBRE-2019.pdf. Accessed 29 October 2020.

28. Moreno, J.O., López Bastida, J., Montejo-González, A.L., Osuna-Guerrero, R., y Duque-González, B. (2009). The socioeconomic costs of mental illness in Spain. European Journal of Health Economics, 10 (4), 361369.

29. INE Database. 2019. https://www.ine.es/dyngs/IOE/es/operacion.htm?numinv=64052. Accessed 29 October 2020.

30. Sakakibara S, Sado M, Ninomiya A, Arai M, Takahashi S, Ishihara C, Miura Y, Tabuchi H, Shirahase J, Mimura M. Predictive factors of the duration of sick leave due to mental disorders. Int J Ment Health Syst. 2019; 13: 19 .

31 Schweitzer L, Su WH. Population density and the rate of mental illness. Am J Public Health. 1977; 67(12): $1165-1172$.

32. Silvaa M; Loureirob A, Cardosoa G. Social determinants of mental health: a review of the evidence. Eur J Psychiat, 2016; 30 (4): 259-292.

33. Näyhä S, Väisänen E, Hassi J. Season and mental illness in an arctic area of northern Finland. Act Psich Scand, 1994; 89: 46-49

34. Vassos E, Agerbo E, Mors O, Pedersen CB. Urban-rural differences in incidence rates of psychiatric disorders in Denmark. Br J Psychiatry. 2016;208(5):435-40.

35 Seedat S, Scott KM, Angermeyer MC, Berglund P, Bromet EJ, Brugha TS, Demyttenaere K, de Girolamo G, Haro JM, Jin R, Karam EG, Kovess-Masfety V, Levinson D, Medina Mora ME, Ono Y, Sampson NA, Williams D, Kessler RC. Cross-national associations between gender and mental disorders in the WHO World Mental Health Surveys. Arch Gen Psychiatry. 2009 Jul; 66(7): 785-795.

36.Persinger MA. Mental processes and disorders: a neurobehavioral perspective in human biometeorology. Experientia, 198;43(1):39-48

37. Cruz J, White PCL, Bell A, Coventry PA. Effect of Extreme Weather Events on Mental Health: A Narrative Synthesis and Meta-Analysis for the UK. Int J Environ Res Public Health. 2020 Nov; 17(22): 8581.

38. Alba Jurado ML, Cabuchola Moreno S. Programa formativo interdisciplinar entre los Inspectores Médicos del Instituto Nacional de la Seguridad Social y los Equipos de Salud Mental en Málaga. Med Segur Trab, 2014: 60 supl.1 
39. Kessler R, Angermeyer M, Anthony JC, de Graaf R, Demyttenaere Ket al on behalf of for the who world mental health survey consortium. Lifetime prevalence and age-of-onset distributions of mental disorders in the World Health Organization's World Mental Health Survey Initiative World Psychiatry, 2007; 6(3): 168176.

40 Roberts T, Esponda GE, Krupchanka D, Shidhaye R, Patel V, Rathod S. Factors associated with health service utilisation for common mental disorders: a systematic review. BMC Psychiatry volume 18, Article number: 262 (2018).

41. Murray G, Allen NB, Rawlings D, Trinder J. Seasonality and personality: a prospective investigation of Five Factor Model correlates of mood seasonality. Eur J Personality, 2002; 16(6): 457-468.

42. Ennis E, McConville C. Personality traits associated with seasonal disturbances in mood and behavior. Curr Psychology, 2004; 22:326-338.

43. Christodoulou NG, Christodoulou GN. Financial Crises: Impact on Mental Health and Suggested Responses. Psychother Psychosom 2013;82:279-284

44. Silva M, Resurrección DM, Antunes A, Frasquilho D, Cardoso G. Impact of economic crises on mental health care: a systematic review. Epidemiol Psychiatr Sci. 2018; 13:1-13.

45. Mingote JC, Adán JC, Gálvez Herrer M, del Pino Cuadrado P, Gutiérrez García MD El paciente que padece un trastorno depresivo en el trabajo. Med Segur Trab 2009; 55 (214): 41-63.

46. Hartz SM, Pato CN, Medeiros H, Cavazos-Rehg P, Sobell JL, Genomic Psychiatry Cohort Consortium (GPCC), Knowles JA, Bierut LJ, Pato MT. Comorbidity of severe psychotic disorders with measures of substance use. JAMA Psychiatry, 2014; 71(3): 248-254.

47. Grau-López L, Daigre Granell A, Grau-López L, Fadeuilhe C, Calcedo-Barba A, Roncero C. Factores asociados a la incapacidad laboral temporal en peritajes psiquiátricos. Actas Esp Psiquiatr 2016;44(4):119-24.

48. Eaton WW., Kramer M., Anthony JC. "The incidence of specific DIS/DSM III mental disorders: Data from the NIMH Epidemiologic Catchment Area Program", Act. Psychiatr Scand 1989, 79, 163-178.

49. Lidwall U, Palmer E, Bohlin CO. Mental disorder sick leave in Sweden: A population study. Work, 2018; 59 (5): $1-14$

50 Henderson M, Harvey SB, Øverland S, Mykletun A, Hotopf M. Work and common psychiatric disorders. J R Soc Med, 2011; 104(5): 198-207.

51 Flach PA, Groothoff JW, Krol B, Bültmann U. Factors associated with first return to work and sick leave durations in workers with common mental disorders. Eur J Public Health, 2012; 22(3): 440-445.

52. D. Gimeno, F. Benavides, B. Amick, J. Benach, and J. M. Martinez. Psychosocial factors and work related sickness absence among permanent and non-permanent employees. J Epidemiol Community Health. 2004 Oct; 58(10): 870-876. 